\title{
Depolarizing Actions of GABA in Immature Neurons Depend Neither on Ketone Bodies Nor on Pyruvate
}

\author{
Roman Tyzio, ${ }^{1}$ Camille Allene, ${ }^{1}$ Romain Nardou, ${ }^{1}$ Michel A. Picardo, ${ }^{1}$ Sumii Yamamoto, ${ }^{1}$ Sudhir Sivakumaran, ${ }^{2}$ \\ Maddalena D. Caiati, ${ }^{2}$ Sylvain Rheims, ${ }^{1}$ Marat Minlebaev, ${ }^{1}$ Mathieu Milh, ${ }^{1}$ Pascal Ferré, ${ }^{3}$ Rustem Khazipov, ${ }^{1}$ \\ Jean-Louis Romette, ${ }^{4}$ Jean Lorquin, ${ }^{5}$ Rosa Cossart, ${ }^{1}$ Ilgam Khalilov, ${ }^{1}$ Astrid Nehlig, ${ }^{6}$ Enrico Cherubini, ${ }^{2}$ \\ and Yehezkel Ben-Ari ${ }^{1}$ \\ ${ }^{1}$ Inserm, Unité 901/Institut de Neurobiologie de la Méditerranée, 13273 Marseille, France, ${ }^{2}$ Neurobiology Department, International School for Advanced \\ Studies, 34012 Basovizza (Trieste), Italy, ${ }^{3}$ Inserm, Unité Mixte de Recherche S872, Centre de Recherche des Cordeliers and Université Pierre et Marie Curie- \\ Paris 6, 75006 Paris, France, ${ }^{4}$ Ecole Supérieur d’Ingénieurs de Luminy, Case 925, 13288 Marseille, France, ${ }^{5}$ Institut de Recherche pour le Développement, \\ Microbiologie et Biotechnologie des Environnements Extrêmes, Unité Mixte de Recherche D180, Université de Provence et de la Méditerranée, 13288 \\ Marseille, France, and 'Inserm, Unité 666, Faculty of Medicine, 67085 Strasbourg, France
}

GABA depolarizes immature neurons because of a high $\left[\mathrm{Cl}^{-}\right]_{\mathrm{i}}$ and orchestrates giant depolarizing potential (GDP) generation. Zilberter and coworkers (Rheims et al., 2009; Holmgren et al., 2010) showed recently that the ketone body metabolite DL-3-hydroxybutyrate (DL-BHB) $(4 \mathrm{mM})$, lactate $(4 \mathrm{mM})$, or pyruvate $(5 \mathrm{mM})$ shifted GABA actions to hyperpolarizing, suggesting that the depolarizing effects of $\mathrm{GABA}$ are attributable to inadequate energy supply when glucose is the sole energy source. We now report that, in rat pups (postnatal days $4-7$ ), plasma D-BHB, lactate, and pyruvate levels are $0.9,1.5$, and $0.12 \mathrm{~mm}$, respectively. Then, we show that DL-BHB (4 mM) and pyruvate $(200 \mu \mathrm{M})$ do not affect (i) the driving force for $\mathrm{GABA}_{\mathrm{A}}$ receptor-mediated currents $\left(\mathrm{DF}_{\mathrm{GABA}}\right)$ in cell-attached single-channel recordings, (2) the resting membrane potential and reversal potential of synaptic $\mathrm{GABA}_{\mathrm{A}}$ receptor-mediated responses in perforated patch recordings, (3) the action potentials triggered by focal GABA applications, or (4) the GDPs determined with electrophysiological recordings and dynamic two-photon calcium imaging. Only very high nonphysiological concentrations of pyruvate $(5 \mathrm{mM})$ reduced $\mathrm{DF}_{\mathrm{GABA}}$ and blocked GDPs. Therefore, DL-BHB does not alter GABA signals even at the high concentrations used by Zilberter and colleagues, whereas pyruvate requires exceedingly high nonphysiological concentrations to exert an effect. There is no need to alter conventional glucose enriched artificial CSF to investigate GABA signals in the developing brain.

\section{Introduction}

GABA depolarizes and excites immature neurons in many animal species because of their higher $\left[\mathrm{Cl}^{-}\right]_{\mathrm{i}}$ compared with mature neurons. This developmental change reflects the sequential operation of the chloride cotransporters NKCC1 and KCC2 (Ben-Ari et al., 1989; Owens et al., 1996; Rivera et al., 1999; Ganguly et al., 2001; Akerman and Cline, 2006) (for review, see Ben-Ari, 2002; Owens and Kriegstein, 2002; Ben-Ari et al., 2007). GABAergic synapses are expressed before glutamatergic synapses, and GABA provides most of the early activity and orchestrates the generation of the first synaptic network-driven giant depolarizing potentials (GDPs) (Ben-Ari et al., 1989; Garaschuk et al., 1998;

\footnotetext{
Received June 27, 2010; revised Sept. 14, 2010; accepted Sept. 20, 2010.

This work was supported by Inserm, L'Agence Nationale de la Recherche (I.K.), Fédération pour la Recherche sur le Cerveau, European Union Network of European Museum Organisations, Fondation pour la Recherche Médicale, and Ministero Istruzione, Università e Ricerca to interface contract with Paris V University (Y.B.-A.). We are grateful to Drs. K. Kaila, P. Legendre, N. Burnashev, G. Chazal, and I. Medina for suggestions and critical remarks. We are grateful to Drs. L. Aniksztejn, F. Libersat, I. Bureau, and J. Epsztein for supervision of the results obtained by the Institut de Neurobiologie de la Méditerranée teams.

Correspondence should be addressed to Yehezkel Ben-Ari, Inserm, Institut de Neurobiologie de la Méditerranée, Unité 901, Campus Scientifique de Luminy 163, route de Luminy BP13, 13009 Marseille, France. E-mail: ben-ari@ inmed.univ-mrs.fr.

DOI:10.1523/JNEUROSCI.3314-10.2011

Copyright $\odot 2011$ the authors $\quad 0270-6474 / 11 / 310034-12 \$ 15.00 / 0$
}

Tyzio et al., 1999; Ben-Ari, 2001; Sipila et al., 2006; Crépel et al., 2007; Bonifazi et al., 2009).

Rodent maternal milk is enriched in fatty acids that are transformed in the liver to aceto-acetate and DL-3-hydroxybutyrate (DL-BHB). On the basis of this information, Zilberter and colleagues have recently challenged the developmental sequence of GABA action (Rheims et al., 2009) and reported that adding DLBHB (4 mM) to artificial CSF (ACSF) almost completely eliminated depolarizing and excitatory actions of GABA. This was suggested to reflect the actions of the $\mathrm{Cl}^{-} / \mathrm{HCO}_{3}^{-}$exchanger and not KCC2, reported to be inactive in the neocortex at the ages investigated [postnatal day 1 (P1) to P8] (Rheims et al., 2009). In a subsequent paper, the same group (Holmgren et al., 2010) extended these observations to hippocampal CA3 pyramidal neurons and reported that, in addition to DL-BHB, lactate or pyruvate at exceedingly high concentrations ( $5 \mathrm{~mm}$ ) also shifted reversal potential of synaptic $\mathrm{GABA}_{\mathrm{A}}$ receptor $\left(\mathrm{GABA}_{\mathrm{A}} \mathrm{R}\right)$-mediated responses $\left(E_{\mathrm{GABA}}\right)$ and blocked GDPs, suggesting that the depolarizing actions of GABA are attributable to energy deprivation when glucose is the sole energetic source. Because this suggestion has important implications for neonatal slice studies, we have now reexamined the effects of $\mathrm{DL}-\mathrm{BHB}$ and pyruvate on GABA actions on neonatal deep layers neocortical neurons and CA3 pyramidal neurons. 
We report that physiological plasma levels of $\mathrm{D}-\mathrm{BHB}$, lactate, and pyruvate are in pups (P5-P7) $0.9,1.5$, and $0.12 \mathrm{~mm}$, respectively. Then, using a wide range of techniques that include extracellular field potential, cell-attached single-channel, and perforated patch-clamp recordings and calcium imaging we report that neither DL-BHB (Sigma-Aldrich) nor physiological concentrations of pyruvate alter GABA actions or spontaneous network dynamics, notably GDPs on rat neocortical and hippocampal neurons. Only very high nonphysiological concentrations of pyruvate altered GABA signaling and GDPs. Our results suggest that depolarizing GABA and GDPs are attributable to neither the absence of $\mathrm{BHB} /$ pyruvate nor the metabolic state of neurons in glucose-containing ACSF.

\section{Materials and Methods}

All investigations were analyzed in a double-blind manner with results obtained by an investigator analyzed by another researcher. In addition, this study was supervised by an independent group of Institut de Neurobiologie de la Méditerranée (INMED) principle investigators that were not involved in research on GABA in the developing brain (see Acknowledgments). They critically reviewed the results that were discussed in internal meetings of all INMED researchers.

\section{Endogenous plasma $D-B H B$, lactate, and pyruvate}

For D-BHB determination, plasma of pups was first deproteinized using $6 \%(\mathrm{w} / \mathrm{v})$ perchloric acid and centrifuged, and the supernatant was neutralized with $\mathrm{KOH}$ before enzymatic determination. D-BHB was determined enzymatically using the spectrophotometric procedure as described previously (Ferré et al., 1983). Dosage of serum lactate and pyruvate were done in the metabolic biochemistry laboratory of Timone Hospital (Marseille, France). Enzymatic technique was used for lactate (RAPIDLAB 1265). Enzymatic dosage based on the reduction of pyruvate to lactate by the lactate dehydrogenase at $\mathrm{pH} 7.5$ with excess nicotinamide adenine dinucleotide was used for the dosage of pyruvate (Vassault, 1991).

\section{Brain slices}

Brain slices were prepared from P4-P8 Wistar rats of both sexes. All animal use protocols conformed to the national guidelines on the use of laboratory animals and were approved by the Animal Care and Use Committees of Inserm and International School for Advanced Studies. Animals were rapidly decapitated, and brains were removed. Coronal slices $(300-500 \mu \mathrm{m})$ were cut using a tissue slicer (Leica-VT1200S; Microm International) in ice-cold oxygenated modified ACSF with $0.5 \mathrm{mM} \mathrm{CaCl}_{2}$ and $7 \mathrm{mM} \mathrm{MgSO}_{4}$, in which $\mathrm{Na}^{+}$was replaced by an equimolar concentration of choline. Slices were then transferred to oxygenated (95\% $\mathrm{O}_{2} / 5 \% \mathrm{CO}_{2}$ ) standard ACSF containing the following (in mM): $126 \mathrm{NaCl}$, $3.5 \mathrm{KCl}, 2.0 \mathrm{CaCl}_{2}, 1.3 \mathrm{MgCl}_{2}, 25 \mathrm{NaHCO}_{3}, 1.2 \mathrm{NaH}_{2} \mathrm{PO}_{4}$, and 10 glucose, $\mathrm{pH} 7.4$, at room temperature $\left(20-22^{\circ} \mathrm{C}\right)$ for at least $1 \mathrm{~h}$ before use. For recordings, slices were placed into a conventional, fully submerged chamber superfused with ACSF $\left(32-34^{\circ} \mathrm{C}\right)$ at a rate of $2-3 \mathrm{ml} / \mathrm{min}$.

\section{Perforated patch-clamp and whole-cell recordings}

Patch-clamp recordings were performed from neocortical pyramidal and CA3 pyramidal neurons using EPC-10 Double (HEKA Elektronik Dr. Schulze GmbH) and Axopatch 200A (Molecular Devices) amplifiers. Patch electrodes were made from borosilicate glass capillaries (GC150F15; Clark Electromedical Instruments). Patch pipette solution for gramicidin perforated patch-clamp recording contained the following (in $\mathrm{mm}$ ): $150 \mathrm{KCl}$ and 10 HEPES, buffered to $\mathrm{pH} 7.2$ with Tris-OH. Gramicidin was first dissolved in DMSO to prepare a stock solution of 10-40 $\mathrm{mg} / \mathrm{ml}$ and then diluted in the pipette solution to a final concentration of $80 \mu \mathrm{g} / \mathrm{ml}$. The gramicidin-containing solution was prepared and sonicated $<1 \mathrm{~h}$ before the experiment. To facilitate cell-attached formation (4-10 G $\Omega$ ), patch pipettes were backfilled with a gramicidin-containing solution. Between 20 and 30 min after formation of the cell-attached seal, the series resistance $\left(R_{\mathrm{s}}\right)$ stabilized at 8-60 M $\Omega$. Series resistance was monitored during all recording sessions. At the end of each recording, negative pressure was applied to break the membrane and establish whole-cell configuration. This was associated with a shift of the reversal potential of the GABA-mediated responses to near $0 \mathrm{mV}$. The membrane potential values $\left(E_{\mathrm{m}}\right)$ were corrected for series resistance offline as $V$ (corrected $)=V$ (holding $)-I R_{\mathrm{s}}$. For whole-cell recordings, we used the pipette solution containing the following (in $\mathrm{mm}$ ): $135 \mathrm{~K}$-gluconate, 20 $\mathrm{KCl}, 10 \mathrm{HEPES}, 4 \mathrm{MgATP}, 0.3 \mathrm{GTP}$, and 0.5 EGTA. A picospritzer (General Valve Corporation) was used to puff apply GABA (100 $\mu \mathrm{M}$ in ACSF) from a glass pipette in stratum radiatum at a distance of $\sim 100 \mu \mathrm{m}$ from the soma in gramicidin perforated patch recordings. The pressure varied from 10 to $20 \mathrm{kPa}$, and the duration of the puff varied from 50 to $200 \mathrm{~ms}$.

Cell-attached recordings of $G A B A_{A}$ and NMDA receptor channels Patch-clamp recordings from visually identified pyramidal cells in a cellattached configuration were performed using an EPC-10 double amplifier or Axopatch 200B amplifier. For recordings of single GABA channels, the following patch pipette solution was added on the day of the experiment from a $1 \mathrm{~mm}$ frozen stock solution (in $\mathrm{mm}$ ): $120 \mathrm{NaCl}, 5 \mathrm{KCl}, 20$ tetraethylammonium-Cl, 5 4-aminopyridine, $0.1 \mathrm{CaCl}_{2}, 10 \mathrm{MgCl}_{2}, 10$ glucose, and 10 HEPES-NaOH, buffered to $\mathrm{pH}$ 7.2-7.3 (with GABA at 1-5 $\mu \mathrm{M}) . E_{\mathrm{m}}$ was estimated using cell-attached recordings of single NMDA receptor (NMDAR) channels as described previously (Tyzio et al., 2003). For recordings of single NMDAR channels, pipette solution contained nominally $\mathrm{Mg}^{2+}$-free ACSF with NMDA $(10 \mu \mathrm{M})$, glycine ( 1 $\mu \mathrm{M})$, and strychnine $(1 \mu \mathrm{M})$. Pipettes (resistance of 3.5-8 M $\Omega$ ) were pulled from borosilicate glass capillaries (GC150F-15; Clark Electromedical Instruments). Recordings were digitized $(10 \mathrm{kHz})$ online with Digidata 1200 or 1440 interface cards (Molecular Devices), filtered (2.9 $\mathrm{kHz}$ ), and analyzed offline with Axon package (Molecular Devices) and Origin (Microcal Software) as described previously (Tyzio et al., 2003, 2006). Group measures are expressed as means \pm SEM; error bars also indicate SEM. The statistical significance of differences was assessed with Student's $t$ test. The level of significance was set at $p<0.05$.

\section{Calcium imaging}

Slice preparation for calcium imaging. Horizontal slices of neocortex and hippocampus (400 $\mu \mathrm{m}$ thick) were prepared from P7 rats using a Vibratome tissue slicer (Leica VT 1200S) in ice-cold oxygenated modified ACSF (mACSF) (with $0.5 \mathrm{~mm} \mathrm{CaCl}_{2}$ and $7 \mathrm{~mm} \mathrm{MgSO}_{4}$; $\mathrm{NaCl}$ replaced by an equimolar concentration of choline). Slices were then transferred for rest $(\sim 1 \mathrm{~h})$ in oxygenated normal ACSF containing the following (in mM): $126 \mathrm{NaCl}, 3.5 \mathrm{KCl}, 1.2 \mathrm{NaH}_{2} \mathrm{PO}_{4}, 26 \mathrm{NaHCO}_{3}, 1.3 \mathrm{MgCl}_{2}, 2.0$ $\mathrm{CaCl}_{2}$, and 10 D-glucose, $\mathrm{pH}$ 7.4. For AM loading, slices were incubated in a small vial containing $2.5 \mathrm{ml}$ of oxygenated ACSF with $25 \mu \mathrm{l}$ of a $1 \mathrm{~mm}$ fura-2 AM solution (in 100\% DMSO; Invitrogen) for 20-30 min. Slices were incubated in the dark, and the incubation solution was maintained at $35-37^{\circ} \mathrm{C}$. Slices were perfused at a rate of $4 \mathrm{ml} / \mathrm{min}$ with continuously aerated $\left(95 \% \mathrm{O}_{2} / 5 \% \mathrm{CO}_{2}\right)$ normal $\mathrm{ACSF}$ at $35-37^{\circ} \mathrm{C}$. Imaging was performed with a multibeam two-photon laser scanning system (Trimscope-LaVision Biotec) coupled to an Olympus microscope as described previously (Crépel et al., 2007). Images were acquired through a CCD camera (La Vision Imager $3 \mathrm{QE}$ ), which typically resulted in a time resolution of $\sim 100 \mathrm{~ms}(2 \times 2$ binning; pixel size, $600 \mathrm{~nm})$. Slices were imaged using a low-magnification, high numerical aperture objective (20×, numerical aperture 0.95 ; Olympus). The size of the imaged field was typically $430 \times 380 \mu \mathrm{m}^{2}$. Imaging depth was on average $80 \mu \mathrm{m}$ below the surface (range, 50-100 $\mu \mathrm{m}$ ).

Analysis of multineuron calcium activity. Analysis of the calcium activity was performed using a previously designed software for neocortical and hippocampal slice analysis (Allène et al., 2008). To summarize briefly, this allowed (1) automatic identification of loaded cells, (2) measuring the average fluorescence transients from each cell as a function of time, and (3) detecting the onsets and offsets of calcium signals. To quantify synchronous activity patterns, we used two parameters: frequency and amplitude and duration of synchronous events. The frequency of a network pattern was derived from the average time interval between two peaks of synchronous activity. The amplitude of a network pattern in a given movie was the average of the maximum of cells coactive in each peak of synchrony across the movie. To identify peaks of synchro- 
nous activity that included more cells than expected by chance, we used interval reshuffling (randomly reordering of intervals between events for each cell) to create set of surrogate event sequences. Reshuffling was performed 1000 times for each movie, and a surrogate histogram was constructed for each reshuffling. The threshold corresponding to a significance level of $p<0.05$ was estimated as the number of coactive cells exceeded in a single frame in only $5 \%$ of these histograms. This threshold was used to calculate the duration of a synchronous activity pattern that is the number of successive frames for which the number of coactive cells was superior to threshold. Experimental values are given as means \pm SEMs. Student's $t$ test and $\chi^{2}$ test were used for statistical comparisons.

Chemical identification of contaminants One milligram of DL-BHB was dissolved in a mixture of ethyl acetate and pentafluoropropionic anhydride (PFPA) (Aldrich) and composed of $80 \mu \mathrm{l}$ each. After $30 \mathrm{~min}$ at $80^{\circ} \mathrm{C}, 1 \mu \mathrm{l}$ of the mixture was directly injected into a gas chromatography-mass spectrometry (GC-MS) instrument (Agilent Technologies) equipped with a $6890 \mathrm{~N}$ GC and a 5973 MSD system. Electron impact mass spectrum of dibenzylamine (DBA) as PFPA derivative was identified in the DL-BHB acid standard from Acros Organics but not in DL-BHB from Sigma-Aldrich. A PFPA was identified as its molecular ion at a mass-to-charge ratio $(\mathrm{m} / \mathrm{z})$ of 383 and a typical fragmentation with the predicted M-91 at $\mathrm{m} / z$ of 252 and the benzyl core at $\mathrm{m} / \mathrm{z}$ of 91. Chromatographic conditions were as follows: DB-1MS capillary column (Agilent Technologies), $30 \mathrm{~m} \times 0.25 \mathrm{~mm}$ inner diameter, film thickness of $1.0 \mu \mathrm{m}$; column temperature, $100-260^{\circ} \mathrm{C}$ at a rate of $4^{\circ} \mathrm{C} /$ $\mathrm{min}$; injection port, $280^{\circ} \mathrm{C}$; gaz vector helium at $1 \mathrm{ml} / \mathrm{min}(10.4 \mathrm{psi})$; electron impact mode at an ionization energy of $70 \mathrm{eV}$. Comparisons of mass spectra were done by using a standard of DBA treated in the same conditions.

\section{Pharmacology}

Bicuculline, 2,3-dihydroxy-6-nitro-7-sulfonyl-benzo[f] quinoxaline, DAPV, DNQX, and CNQX were purchased from Tocris Bioscience; DL-BHB was from Sigma-Aldrich (catalog \#54965, batch \#1316259 31908044) and from Acros Organics. Isoguvacine, dybenzylamine, GABA, lactate, and pyruvate were from Sigma. TTX was from Ascent Scientific Ltd.

\section{Results \\ Blood concentrations of $\mathrm{D}-\mathrm{BHB}$, lactate, and pyruvate in neonatal rodent}

In newborn rodents, the blood levels of active $\mathrm{D}-\mathrm{BHB}$ are in the submillimolar range (see Discussion). We reinvestigated this issue, using an assay that determines $\mathrm{D}-\mathrm{BHB}$ levels, and found that, in $\mathrm{P} 7$ rats, the $\mathrm{D}-\mathrm{BHB}$ plasma concentration was $0.91 \pm 0.15 \mathrm{~mm}$ $(n=14)$. We measured D-BHB levels after administration of insulin $(0.33 \mathrm{U} / \mathrm{kg}$, i.m. $)$ to inhibit fatty acid oxidation and 2-mercaptoacetate $(100 \mathrm{mg} / \mathrm{kg}$, i.p.) to inhibit mitochondrial acyl-CoA dehydrogenase with $5 \mathrm{~mm}$ glucose to prevent hypoglycemia. This treatment strongly and rapidly (within $1 \mathrm{~h}$ ) reduced the plasma level of the D-BHB to $0.14 \pm 0.03 \mathrm{~mm}(n=14)$. Conversely, injections of exogenous $4 \mathrm{mM}$ DL-BHB increased the blood D-BHB concentration to $1.74 \pm 0.42 \mathrm{mM}(n=7)$. Using conventional hospitals kits, plasma lactate and pyruvate levels at P4 were of $1.5 \pm 0.25 \mathrm{~mm}$ and $123 \pm 16 \mu \mathrm{M}$, respectively $(n=5)$. Therefore, plasma D-BHB, pyruvate, and lactate concentrations are much lower than those used by Zilberter and colleagues ( 4

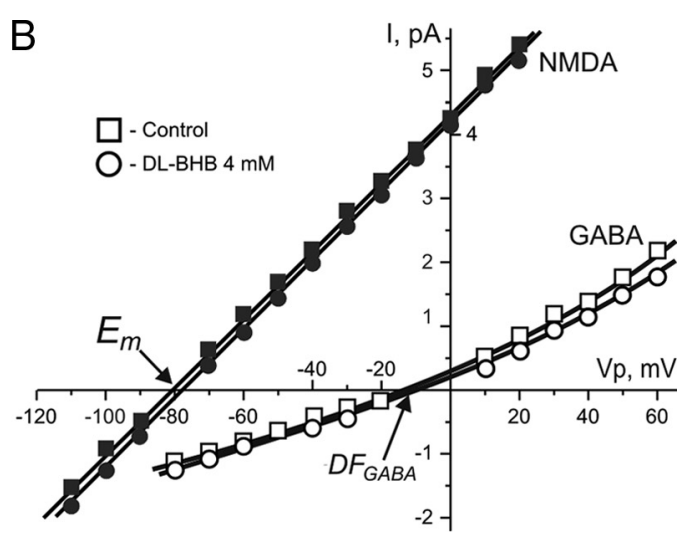

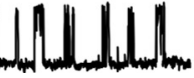

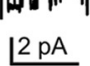

$100 \mathrm{~ms}$ of $\mathrm{DF}_{\mathrm{GABA}}$ and $E_{\mathrm{m}}$ from the same neocortical cell. $\boldsymbol{A}$, Scheme of consecutive $\left.F_{G A B A}\right)$. These two measurements allow us to determine $E_{G A B A}$ for this neuron. Then, we applied DL-BHB for 40 min and repeated the recordings with the same sequence (NMDAR and then GABA $A$ channels). Thus, every cell studied was patched four times. Representative traces of recordings of the single-channel openings are voltage relationships of NMDAR channels were best fitted with linear function (Tyzio et al., 2003, 2008). Note that application of $\mathrm{DL}-\mathrm{BHB}$ does not change significantly $\mathrm{DF}_{\mathrm{GABA}}$ and $E_{\mathrm{m}}$.

$\mathrm{mM}$ DL-BHB, $5 \mathrm{~mm}$ pyruvate, and $5 \mathrm{~mm}$ lactate). The difference is particularly high for pyruvate (40-fold) (see Discussion).

\section{DL-BHB (from Sigma-Aldrich) does not alter the driving force} for somatic $\mathrm{GABA}_{\mathrm{A}} \mathrm{R}$-mediated currents

The binding of GABA to $\mathrm{GABA}_{\mathrm{A}}$ receptors opens channels permeable notably to chloride. The resulting trans-membrane chloride current can either depolarize or hyperpolarize the membrane according to its $E_{\mathrm{GABA}}$ and $E_{\mathrm{m}}$ of the cell. As indicated in previous studies, measurement of $E_{\mathrm{m}}$ using NMDAR channels as the voltage sensor has an advantage over the other microelectrode techniques especially in immature cells with high input resistance (Tyzio et al., 2003). Single NMDAR and $\mathrm{GABA}_{\mathrm{A}} \mathrm{R}$ channels were recorded from either the same neurons or from different neurons to determine $E_{\mathrm{m}}$ and driving force for somatic $\mathrm{GABA}_{\mathrm{A}} \mathrm{R}$-mediated currents $\left(\mathrm{DF}_{\mathrm{GABA}}\right)$ and thereby allow a precise determination of $E_{\mathrm{GABA}}$ (Tyzio et al., 2008). As in the studies by Rheims et al. (2009) and Holmgren et al. (2010), slices were incubated in $4 \mathrm{mM}$ DL-BHB (Sigma-Aldrich) for at least $40 \mathrm{~min}$ and then transferred to a recording chamber in which they were continuously superfused with the same concentration of DL-BHB.

We first determined $E_{\mathrm{GABA}}$ by alternate cell-attached recordings (in sum, four attempts for every cell) of NMDAR and $\mathrm{GABA}_{\mathrm{A}} \mathrm{R}$ single channels from the soma of the same neuron in the neocortex (Fig. 1). As shown in Table 1, DL-BHB altered neither $E_{\mathrm{m}}$ nor $E_{\mathrm{GABA}}$ in neocortical neurons (P4-P5 rats) of both superficial and deep layers (all $p>0.05$ ). Similar results were obtained when single NMDAR and $\mathrm{GABA}_{\mathrm{A}} \mathrm{R}$ channels were recorded in different neurons (to avoid the potential local membrane alterations): $\mathrm{DF}_{\mathrm{GABA}}$ in hippocampal CA3 pyramidal cells was not significantly different in control and $4 \mathrm{mM}$ DL-BHB (Table 2) $(p>0.05) ; E_{\mathrm{m}}$ in the same population of cells also did not change significantly in DL-BHB $(p>0.05)$. Similarly, in both superficial and deep layers of the neocortex, $\mathrm{DF}_{\mathrm{GABA}}$ was strongly depolarizing in control conditions and in the presence of DL$\mathrm{BHB}$; the values of $E_{\mathrm{m}}$ were similar in control conditions and in the presence of DL-BHB (all $p>0.05$ ) (Table 2). Therefore, DL- 
Table 1. Double measurement of $\mathrm{DF}_{\mathrm{GABA}}$ and $E_{\mathrm{m}}$ from the same neocortical cell reveal that $\mathrm{DL}-\mathrm{BHB}$ does not alter $E_{\mathrm{GABA}}$ in pyramidal neocortical cells

\begin{tabular}{lrr}
\hline & Regular ACSF & ACSF + DL-BHB at 4 mM \\
\hline$n$ & \multicolumn{1}{l}{} & 6 \\
$E_{\mathrm{m}}(\mathrm{mV})$ & $-81.7 \pm 2.6$ & $-79.2 \pm 2.9$ \\
$\mathrm{DF}_{\mathrm{GABA}}(\mathrm{mV})$ & $14.8 \pm 3.3$ & $13.7 \pm 3.1$ \\
$E_{\mathrm{GABA}}(\mathrm{mV})$ & $-66.9 \pm 3.9$ & $-65.5 \pm 3.1$ \\
\hline
\end{tabular}

$\mathrm{DF}_{\mathrm{GABA}}$ inferred from $/-V$ curves of single $\mathrm{GABA}_{\mathrm{A}} \mathrm{R}$ channels, $E_{\mathrm{m}}$ inferred from $1-V$ curves of single NMDAR, and the $G A B A_{A} R$ channels reversal potential.

BHB alters neither $E_{\mathrm{m}}$ nor $E_{\mathrm{GABA}}$ in neocortical and hippocampal neurons.

\section{DL-BHB does not alter the polarity of synaptic GABAergic responses}

We then used perforated patch recordings to determine the effects of DL-BHB on synapse-driven $\mathrm{GABA}_{\mathrm{A}} \mathrm{R}$-mediated postsynaptic potentials (GPSPs). In immature hippocampal slices, GABA released from MF terminals exerts a depolarizing action on CA3 principal cells in gramicidin perforated patch recordings (Sivakumaran et al., 2009). With gramicidin patch recordings from CA3 pyramidal cells, the resting membrane potential was $-56 \pm 2.2 \mathrm{mV}(n=10)$ (Fig. $2 A-C)$. The more depolarized $E_{\mathrm{m}}$ value found with these experiments (with respect to that observed in cell-attached recordings) could be attributed to the leakage via gigaseal contact introduced in perforated patch recordings (Barry and Lynch, 1991; Tyzio et al., 2003). In the presence of $20 \mu \mathrm{M}$ DNQX and $50 \mu \mathrm{M}$ D-AP-5 to block AMPA and NMDA receptors, respectively, local stimulation of GABAergic interneurons in stratum radiatum generated PSPs with reversed polarity $\left(E_{\mathrm{GPSPs}}\right)$ at $-47.6 \pm 3.3 \mathrm{mV}(n=10)$. The driving force for $\mathrm{GABA}$ was $\sim 9 \mathrm{mV}$ positive to $E_{\mathrm{m}}$, indicating that GABA is depolarizing from the resting potential as a result of the activity of chloride accumulating NKCC1 cotransporter (Tyzio et al., 2003, 2007; Sipila et al., 2006). Addition of DL-BHB ( $4 \mathrm{~mm}$ for at least 40 min) altered neither $E_{\mathrm{m}}(-60 \pm 1 \mathrm{mV})$ nor $E_{\mathrm{GPSPs}}(-48 \pm 2 \mathrm{mV}$; $n=11$ ), with an average $\mathrm{DF}_{\mathrm{GABA}}$ of $\sim 12 \mathrm{mV}$. The values of $E_{\mathrm{m}}$ and $E_{\mathrm{GPSPs}}$ obtained in the presence of DL-BHB were not significantly different from those obtained in the absence of DL-BHB ( $p>0.05$ for both) (Fig. $2 A-C$ ). Therefore, DL-BHB does not alter $E_{\mathrm{GPSPs}}$.

We also used gramicidin perforated patch recordings to determine whether DL-BHB alters the response evoked by $\mathrm{GABA}_{\mathrm{A}}$ receptor agonists. The reversal of isoguvacine-evoked responses $\left(E_{\text {iso }}\right)$ was determined in control and during bath application of 4 $\mathrm{mM} \mathrm{DL}-\mathrm{BHB}$ for at least $40 \mathrm{~min}$. Isoguvacine $(40 \mu \mathrm{M}$, from a holding potential of $-60 \mathrm{mV}$ ) generated inward currents that reversed at $-48 \pm 3 \mathrm{mV}$ in control $(n=6)$ and $-47 \pm 3 \mathrm{mV}$ in the presence of DL-BHB $(n=6)$. These values were not significantly different $(p>0.05)$ (Fig. $2 D)$.

Furthermore, in three cells kept in current-clamp conditions in the presence of blockers of fast synaptic transmission (DNQX at $50 \mu \mathrm{M}, \mathrm{D}-\mathrm{APV}$ at $50 \mu \mathrm{M}$, and bicuculline at $10 \mu \mathrm{M}$ ), bath application of $4 \mathrm{mM}$ DL-BHB altered neither the resting membrane potential nor the input resistance [values for $E_{\mathrm{m}}$ and $R_{\mathrm{in}}$ were $-60 \pm 3$ and $-61 \pm 2 \mathrm{mV}(n=6)$ and $625 \pm 37$ and $575 \pm 42$ $\mathrm{M} \Omega(n=6$, all $p>0.05)$, before and $40 \mathrm{~min}$ after DL-BHB application, respectively] (supplemental Fig. 1, available at www. jneurosci.org as supplemental material).

\section{DL-BHB does not alter the excitatory effects of GABA}

To determine whether DL-BHB alters the excitatory actions of GABA, we focally applied GABA on neurons recorded in cell- attached configuration in the presence of CNQX $(10 \mu \mathrm{M}), \mathrm{APV}(40 \mu \mathrm{M})$, and CGP 55845 ((2S)-3-[[(1S)-1-(3,4-dichlorophenyl)ethyl] amino-2-hydroxypropyl](phenylmethyl)phosphinic acid hydrochloride) $(2 \mu \mathrm{M})$ to block ionotropic glutamate and metabotropic $\mathrm{GABA}_{\mathrm{B}}$ receptors.

In these conditions, GABA triggered spikes and this action was reversibly blocked by the $\mathrm{GABA}_{\mathrm{A}}$ receptor antagonists (data not shown), indicating that they were generated by the activation of $\mathrm{GABA}_{\mathrm{A}}$ receptors. As shown in Figure $3 A$, focal applications of GABA, in the hippocampus in the presence of DL-BHB generated a similar number of spikes as in controls $(1.29 \pm 0.09$ spikes in control and $1.44 \pm 0.1$ in DL-BHB, $n=7, p>0.05)$. Similar results were obtained with neocortical layer $\mathrm{V}$ pyramidal neurons $(1.39 \pm 0.06$ spikes in control and $1.23 \pm 0.05$ in the presence of DL-BHB, $n=6, p>0.05)$. The specific NKCC1 antagonist bumetanide $(10 \mu \mathrm{M})$ prevented GABA from inducing spikes generated by focal applications of GABA in the presence of the same mixture and DL-BHB, confirming that they were generated by depolarizing actions of GABA (Fig. $3 B)(n=3)$. Therefore, DLBHB applied in conditions similar to those used by Rheims et al. (2009) and Holmgren et al. (2010) does not alter the driving force and reversal potential of somatic (extrasynaptic) and synaptic GABA activated responses, the resting membrane potential, and excitatory actions of GABA on neocortical or hippocampal neurons.

\section{DL-BHB does not alter GDPs}

We next examined whether DL-BHB affects GDPs, which are dependent on depolarizing actions of GABA and are very sensitive to alterations of neuronal excitability and to insufficient energy supply (Ben-Ari et al., 1989; Dzhala et al., 1999; Allène et al., 2008). As shown in Figure 4, GDPs occurred synchronously with extracellular field potentials and were readily identified in wholecell recordings by their characteristic shape and kinetics. DL-BHB altered neither the frequency $[0.054 \pm 0.005$ and $0.046 \pm 0.004$ $\mathrm{Hz}$ in control $(n=7)$ and DL-BHB $(n=8)$, respectively; $p>0.05$ ] nor the integrated area under GDPs $[26.6 \pm 3.1 \mathrm{mV} / \mathrm{s}(n=6)$ and $24.3 \pm 3.2 \mathrm{mV} / \mathrm{s}(n=7)$ in control and DL-BHB, respectively; $p>0.05$ ].

We next used fast multineuron calcium imaging to measure the actions of DL-BHB on neuronal activity synchronization in cortical networks. This approach enables investigating the spatiotemporal dynamics of spontaneous neuronal activity in large neocortical and hippocampal networks with single-cell resolution. With this approach, immature hippocampal and neocortical networks display similar correlated activity patterns composed of synchronous plateau assemblies (SPAs) and GDPs that are both strongly modulated by the excitatory action of GABA (Crépel et al., 2007; Allène et al., 2008; Bonifazi et al., 2009). These patterns can be easily identified in single cells based on their characteristic calcium dynamics because SPAs are associated with long-lasting $(\sim 10-20 \mathrm{~s}$ on average $)$ calcium plateau potentials synchronized across small groups of neurons, whereas the intracellular calcium correlate of GDPs are fast calcium transients ( $\sim 250 \mathrm{~ms}$ ) decay (Crépel et al., 2007; Allène et al., 2008) synchronizing larger neuronal populations. To determine whether DL-BHB affected neuronal calcium dynamics, multibeam two-photon imaging in neocortical slices loaded with a calcium indicator (fura-2 AM) was performed. Slices were incubated in $4 \mathrm{~mm}$ DL-BHB for at least $40 \mathrm{~min}$. Custom software was used to measure fluorescence changes in each cell and to mark the onset and offset of individual calcium transients (see Materials 
Table 2. DL-BHB does not alter $\mathrm{DF}_{\mathrm{GABA}}$ and $E_{\mathrm{m}}$ in principal cells of rat hippocampus and neocortex: changes of $\mathrm{DF}_{\mathrm{GABA}}$ determined with cell-attached recording of $\mathrm{GABA}_{\mathrm{A}} \mathrm{R}$ channels in hippocampal CA3 cells and both superficial and deep layers of neocortex

\begin{tabular}{|c|c|c|c|c|}
\hline & \multicolumn{2}{|l|}{ Hippocampus } & \multicolumn{2}{|l|}{ Neocortex } \\
\hline & regular ACSF & $\mathrm{ACSF}+\mathrm{DL}-\mathrm{BHB}$ at $4 \mathrm{~mm}$ & regular ACSF & $\mathrm{ACSF}+\mathrm{DL}-\mathrm{BHB}$ at $4 \mathrm{~mm}$ \\
\hline$E_{\mathrm{m}}(\mathrm{mV})$ & $-77.8 \pm 3.5(n=9)$ & $-76.2 \pm 4.2(n=12)$ & $-72.2 \pm 5.4(n=5)$ & $-70.6 \pm 3.2(n=7)$ \\
\hline $\mathrm{DF}_{\mathrm{GABA}}(\mathrm{mV})$ & $19.8 \pm 6.5(n=12)$ & $16.5 \pm 3.5(n=14)$ & $22.9 \pm 4.2(n=10)$ & $18.2 \pm 3.6(n=11)$ \\
\hline
\end{tabular}

Note that, in this set of experiments, $\mathrm{DF}_{\mathrm{GABA}}$ and $E_{\mathrm{m}}$ were examined in different cells.
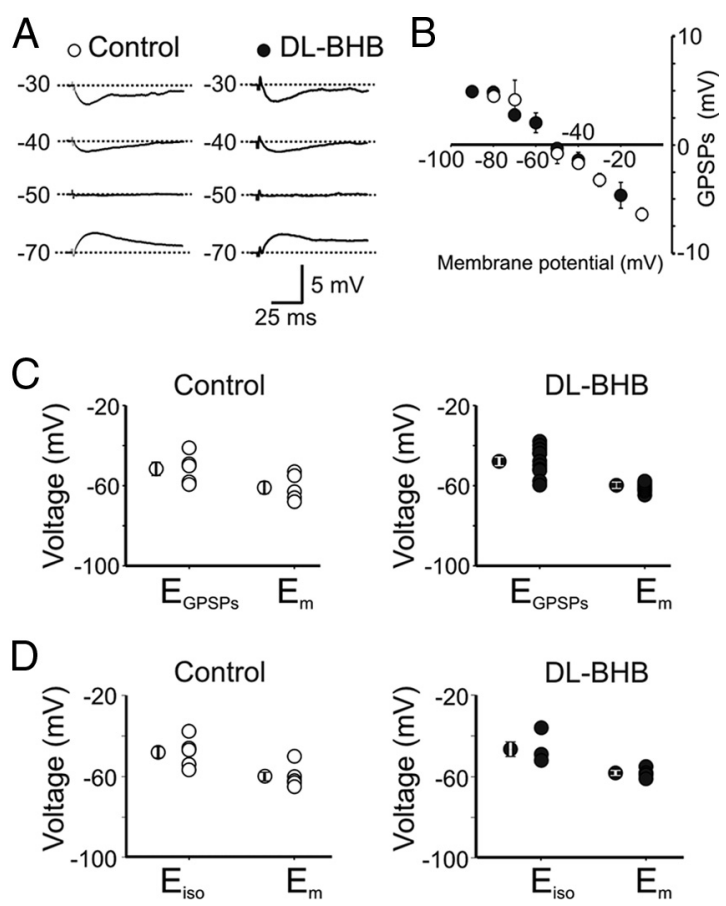

Figure 2. DL-BHB does not alter the polarity of GABAergic responses in CA3 pyramidal cells. $\boldsymbol{A}$, Example of $\mathrm{GABA}_{A}$-mediated postsynaptic potentials evoked in control and in the presence of 4 $\mathrm{mM} \mathrm{DL}-\mathrm{BHB}$ at four different holding potentials (to the left of the traces) by local stimulation of GABAergic interneurons in stratum radiatum. $\boldsymbol{B}$, The mean GPSP amplitudes obtained in 11 cells are plotted against membrane potentials $\left(E_{\mathrm{m}}\right)$. Vertical bars represent the SEM. $\boldsymbol{C}$, Each symbol represents the $E_{\mathrm{GPSPs}}$ and the $E_{\mathrm{m}}$ of individual cells. Average values are shown on the left of each group (control: $E_{\mathrm{GPSPs}}=-47.6 \pm 3.3 \mathrm{mV}, E_{\mathrm{m}}=-56 \pm 2.2 \mathrm{mV}, n=10$; in DL-BHB: $E_{\mathrm{GPSPs}}=$ $\left.-48.2 \pm 2 \mathrm{mV}, E_{\mathrm{m}}=-60 \pm 1 \mathrm{mV}, n=11\right)$. $D$, The $E_{\text {iso }}$ was determined in control and during bath application of DL-BHB ( $4 \mathrm{~mm}$, for at least $40 \mathrm{~min}$ ). The isoguvacine application (40 $\mu \mathrm{m}$ ) generated the responses, which reversed at $-48 \pm 3 \mathrm{mV}$ in control $(n=6)$ and $-47 \pm 3 \mathrm{mV}$ in DL-BHB $(n=6)$, respectively. These values were not significantly different $(p>0.05)$.

and Methods). In these conditions, we did not find any significant decrease in either the fraction of neurons producing SPAs or the frequency and amplitude of GDPs in neocortical slices $(p>$ 0.05, $n=5$ slices) (Fig. 5, Table 3). As a positive control for excitatory GABA actions, we applied the NKCC1 antagonist bumetanide $(10 \mu \mathrm{M})$. Bumetanide significantly reduced the occurrence of GDPs both in regular ACSF and in the presence of DL-BHB (Fig. 5). Frequency and amplitude of GDPs were reduced to $26 \pm$ 21 and $38 \pm 10 \%$, respectively, in regular $\operatorname{ACSF}(n=7, p<0,05)$ and to $12 \pm 7$ and $56 \pm 34 \%$, respectively, in DL-BHB conditions $(n=5, p<0.05)$. As reported previously in hippocampal slices (Crépel et al., 2007), the fraction of SPA cells was significantly increased in the presence of bumetanide $(10 \mu \mathrm{M}$, to $535 \pm 192$ and $349 \pm 104 \%$ in regular ACSF and DL-BHB, respectively, $n=$ $5, p<0.05)$. The effects of bumetanide cannot be reconciled with a reduction of the depolarizing action of GABA in the presence of DL-BHB (Rheims et al., 2009) (see Discussion).
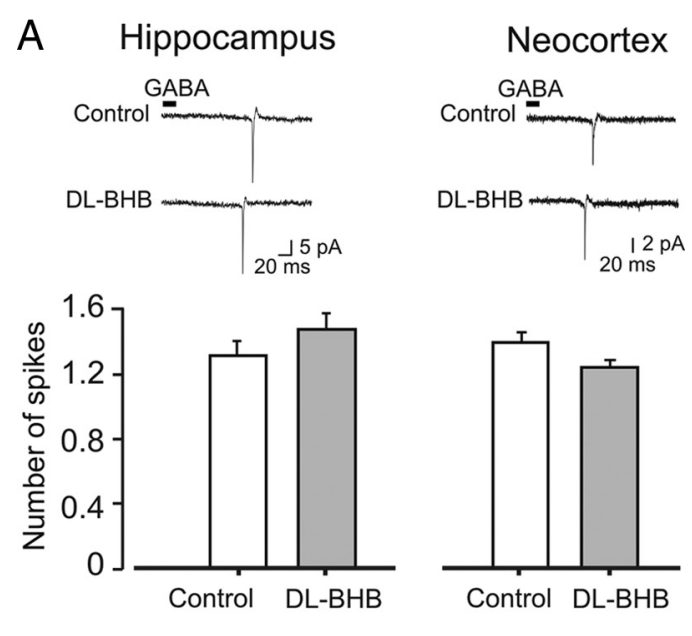

$\mathrm{B}$

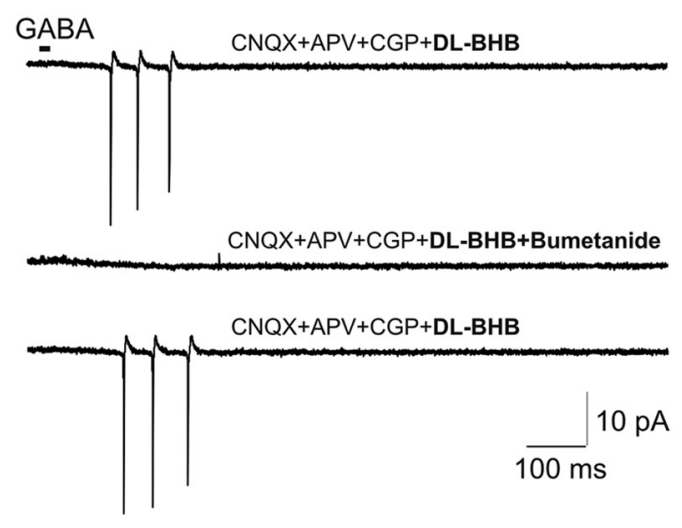

Figure 3. DL-BHB does not alter the excitation produced by focal application of GABA in both hippocampus and neocortical pyramidal neurons. $A$, Each column represents number of spikes induced by focal application of GABA (top traces) recorded in cell-attached mode from hippocampus and neocortex in control and in presence of $4 \mathrm{~mm}$ DL-BHB. $\boldsymbol{B}$, Bumetanide (10 $\mu \mathrm{m})$ fully blocked the spikes generated by focal applications of GABA in the presence of the same mixture and DL-BHB $(n=3)$.

\section{A contamination in DL-BHB (from Acros Organics)} reduces $\mathrm{DF}_{\mathrm{GABA}}$

While conducting our experiments, we found that DL-BHB from another source (Acros Organics) gave different results. In slices incubated in $4 \mathrm{~mm}$ DL-BHB (Acros Organics for at least $40 \mathrm{~min}$ ), $\mathrm{DF}_{\mathrm{GABA}}$ measured using cell-attached recordings of $\mathrm{GABA}_{\mathrm{A}} \mathrm{R}$ channels was significantly reduced in CA3 pyramidal cells from $12.2 \pm 3.9 \mathrm{mV}(n=6)$ to $0.47 \pm 3.04 \mathrm{mV}(n=10, p<0.05$; data not shown). Similar effects of DL-BHB (Acros Organics) were found with perforated patch recordings of GPSPs evoked by local stimulation of GABAergic interneurons in stratum radiatum in the presence of DNQX $(20 \mu \mathrm{M})$ and D-APV $(50 \mu \mathrm{M})$. As shown in supplemental Figure 2 (available at www.jneurosci.org as supplemental material), DL-BHB from Acros Organics (applied for at least $45 \mathrm{~min}$ ) hyperpolarized the membrane and shifted $E_{\mathrm{GPSP}}$ toward more negative values (on average, on seven neurons $E_{\mathrm{m}}$ 
A
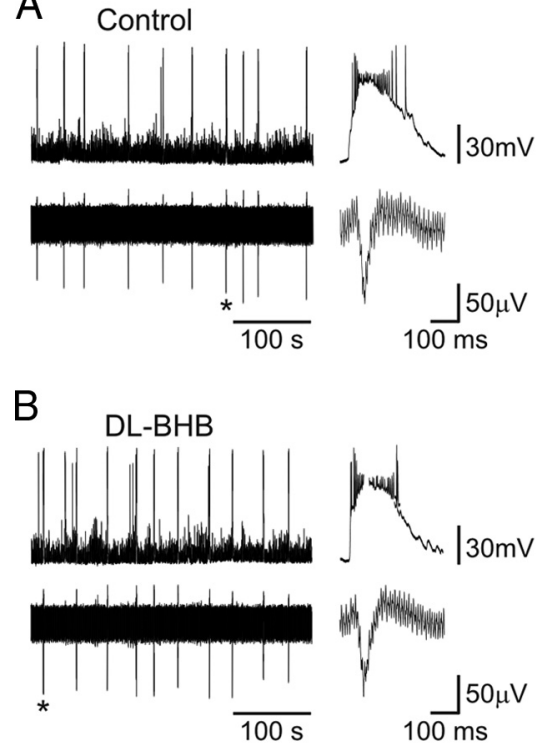

B

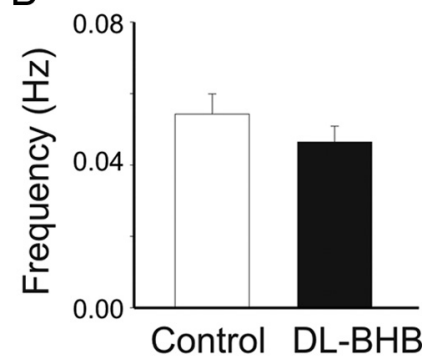

$\mathrm{D}$

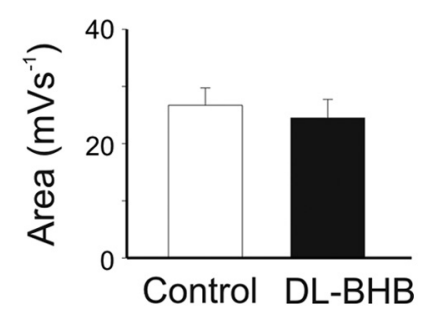

Figure 4. DL-BHB does not alter spontaneous neuronal activity patterns at early postnatal stages in hippocampal slices. $\boldsymbol{A}, \boldsymbol{B}$, Individual traces of spontaneous GDPs recorded at $-70 \mathrm{mV}$ from CA3 pyramidal cell (top traces) and field potentials (bottom traces) in slice exposed to ACSF (control, $A$ ) or ACSF plus DL-BHB at $4 \mathrm{~mm}$. $B$, DL-BHB did not alter the frequency or the shape of GDPs (shown on the right in an expanded timescale). $\boldsymbol{C}, \boldsymbol{D}$, Each column represent the mean GDPs frequency $(\boldsymbol{C})$ or area $(\boldsymbol{D})$ in control (white; $n=6$ ) or during bath application of DL-BHB (black; $n=7$ ). ${ }^{*} p<0.01$.

and $E_{\mathrm{GPSPs}}$ were $-80 \pm 4$ and $-67 \pm 4 \mathrm{mV}$, respectively). In additional experiments, we tested the actions of DL-BHB (Acros Organics) on GDPs using calcium imaging. As shown in supplemental Figure 3 (available at www.jneurosci.org as supplemental material), DL-BHB (Acros Organics) reduced the frequency and amplitude of GDPs in neocortical slices (from $0.12 \pm 0.02$ to $0.02 \pm 0.01 \mathrm{~Hz}$ and from $22 \pm 3$ to $5 \pm 4 \%$ of active cells, $n=5$, $p<0.05$ ). Therefore, DL-BHB (Acros Organics) reduces DFGABA and alters GDPs.

Because previous studies reported the presence of a contaminant in L-BHB (Donevan et al., 2003) (see Discussion), we decided to test whether a similar contaminant was also present in DL-BHB obtained from this source (Acros Organics). Using a GC-MS instrument, several contaminants were found in this source of DL-BHB, notably DBA as PFPA derivative identified in the DL-BHB from Acros Organics (supplemental Fig. 4, available at www.jneurosci.org as supplemental material) but not in DLBHB (Sigma-Aldrich; data not shown). We therefore tested the actions of DBA on $\mathrm{DF}_{\mathrm{GABA}}$ and found that $50 \mu \mathrm{M}$ DBA switched $\mathrm{DF}_{\mathrm{GABA}}$, determined with single-channel recordings, from depolarizing $12.8 \pm 2.8 \mathrm{mV}(n=10)$ to hyperpolarizing $-2.9 \pm 2.2$ $\mathrm{mV}(n=10, p<0.001$; data not shown $)$. With whole-cell recordings, DBA also blocked GDPs in a concentration-dependent way with an $\mathrm{EC}_{50}$ of $57 \mu \mathrm{M}$ (supplemental Fig. 5, available at www. jneurosci.org as supplemental material). The dose-response curve was steep: whereas at $60 \mu \mathrm{M}$ DBA severely reduced the frequency of GDPs from $0.046 \pm 0.007$ to $0.01 \pm 0.002 \mathrm{~Hz}$, at 80 $\mu \mathrm{M}$ it completely abolished them $(n=10)$. These observations suggest that DL-BHB does not alter GABA signals, but care must be taken when using BHB compounds to ensure absence of contaminants. We next investigated the actions of pyruvate on the same parameters.

\section{High but not physiological concentrations of pyruvate affect GABA signaling}

We first tested the effect of pyruvate at $5 \mathrm{~mm}$ on $\mathrm{DF}_{\mathrm{GABA}}$ in singlechannel recordings of CA3 pyramidal cells from P7 rat hip-

pocampus. $\mathrm{DF}_{\mathrm{GABA}}$ shifted from $12.2 \pm$ $5.7 \mathrm{mV}$ in control $(n=9)$ to $0.4 \pm 3 \mathrm{mV}$ in pyruvate $(n=9, p<0.01$; data not shown). In contrast, more relevant physiological concentrations $(200 \mu \mathrm{M})$ did not significantly change $\mathrm{DF}_{\mathrm{GABA}}$ $(7.1 \pm 3.2 \mathrm{mV}$ in control, $n=7$ and $6.7 \pm 2.5 \mathrm{mV}$ in pyruvate, $n=8, p>$ 0.05 ; data not shown). Therefore, pyruvate does not affect $\mathrm{DF}_{\mathrm{GABA}}$ at physiological levels and alters $\mathrm{DF}_{\mathrm{GABA}}$ only at excessively high concentrations.

Gramicidin perforated patch experiments were performed to assess whether pyruvate alters $E_{\mathrm{m}}$ and $E_{\mathrm{GPSPs}}$. Like DL$\mathrm{BHB}$, the addition of a physiological concentration of $200 \mu \mathrm{M}$ pyruvate to the ACSF did not modify $E_{\mathrm{m}}$ and $E_{\mathrm{GPSPs}}$ (Fig. 6). $E_{\mathrm{m}}$ values were $-56.8 \pm 0.9$ and $-57.1 \pm 1.02 \mathrm{mV}$ in control and in the presence of pyruvate, respectively $(p>$ $0.05, n=7)$. In contrast, $5 \mathrm{~mm}$ pyruvate caused a negative shift of $E_{\mathrm{GPSPs}}$ (from $-48.3 \pm 1.9$ to $-55.7 \pm 3 \mathrm{mV}, n=7$ ) without altering $E_{\mathrm{m}}\left(E_{\mathrm{m}}\right.$ values were $-56.8 \pm 0.9$ and $-56.6 \pm 1.8 \mathrm{mV}$ in control and in the presence of $5 \mathrm{~mm}$ pyruvate, respectively, $n=7$ ). The driving force for GABA was $\sim 0.9 \mathrm{mV}$ positive to $E_{\mathrm{m}}$, indicating that GABA does not exert a depolarizing action. The $E_{\mathrm{GPSPs}}$ value observed in the presence of $5 \mathrm{~mm}$ pyruvate was significantly different from that obtained in control $(p=0.003)$ or in the presence of $200 \mu \mathrm{M}$ pyruvate $(p=0.005)$. $E_{\mathrm{m}}$ and $E_{\mathrm{GPSPs}}$ were unaffected by the further addition of DL-BHB to $5 \mathrm{~mm}$ pyruvate. In the presence of $4 \mathrm{~mm}$ DL-BHB and $5 \mathrm{~mm}$ pyruvate, $E_{\mathrm{m}}$ and $E_{\mathrm{GPSPs}}$ were $-57.4 \pm 2.5$ and $-59.6 \pm 2.9 \mathrm{mV}$, respectively $(n=6)$. These values are similar to those obtained when cells were exposed only to pyruvate (data not shown).

Furthermore, with extracellular field potential recordings from the CA3 region ( $\mathrm{P} 4-\mathrm{P} 7)$, pyruvate at a physiological concentration did not affect the frequency of GDPs $(0.06 \pm 0.008$ and $0.06 \pm 0.01 \mathrm{~Hz}$ in control and in the presence of $200 \mu \mathrm{M}$ pyruvate, respectively; $p>0.05, n=6$ ) (Fig. 7). In contrast, in the presence of $5 \mathrm{~mm}$ pyruvate, the frequency of GDPs severely depressed (from $0.06 \pm 0.008$ to $0.02 \pm 0.007 \mathrm{~Hz}, p=0.005, n=6$ ).

Similar observations were made with imaging techniques. We monitored spontaneous neuronal activity in neocortical and hippocampal slices bathed in mACSF that mimics physiological conditions (lactate at $1.5 \mathrm{~mm}$, pyruvate at $150 \mu \mathrm{M}$, and DL-BHB at 2 $\mathrm{mm}$; see Discussion). There was no change in GDPs or SPA patterns of activity (Fig. 8, Table 4$)(p>0.05$, five neocortical slices and three hippocampal slices). Indeed, the frequency of neocortical GDPs in mACSF was $0.1 \pm 0.02 \mathrm{~Hz}$ compared with $0.12 \pm$ $0.02 \mathrm{~Hz}$ in control conditions, and the amplitude of neocortical GDPs was $24 \pm 4$ compared with $22 \pm 3 \%$ of active cells in regular ACSF. The frequency of hippocampal GDPs in mACSF was not affected either $(0.07 \pm 0.03$ vs $0.1 \pm 0.03 \mathrm{~Hz}$ in control conditions). In contrast, pyruvate $(5 \mathrm{~mm})$, added to regular ACSF, significantly reduced the frequency and amplitude of hippocampal GDPs to $8 \pm 7$ and $53 \pm 33 \%$ of control conditions, respectively (supplemental Fig. 6) $(n=5, p<0.05)$. Therefore, pyruvate alters GABA postsynaptic currents and GDPs only at high nonphysiological concentrations. 


\section{Regular ACSF}

A
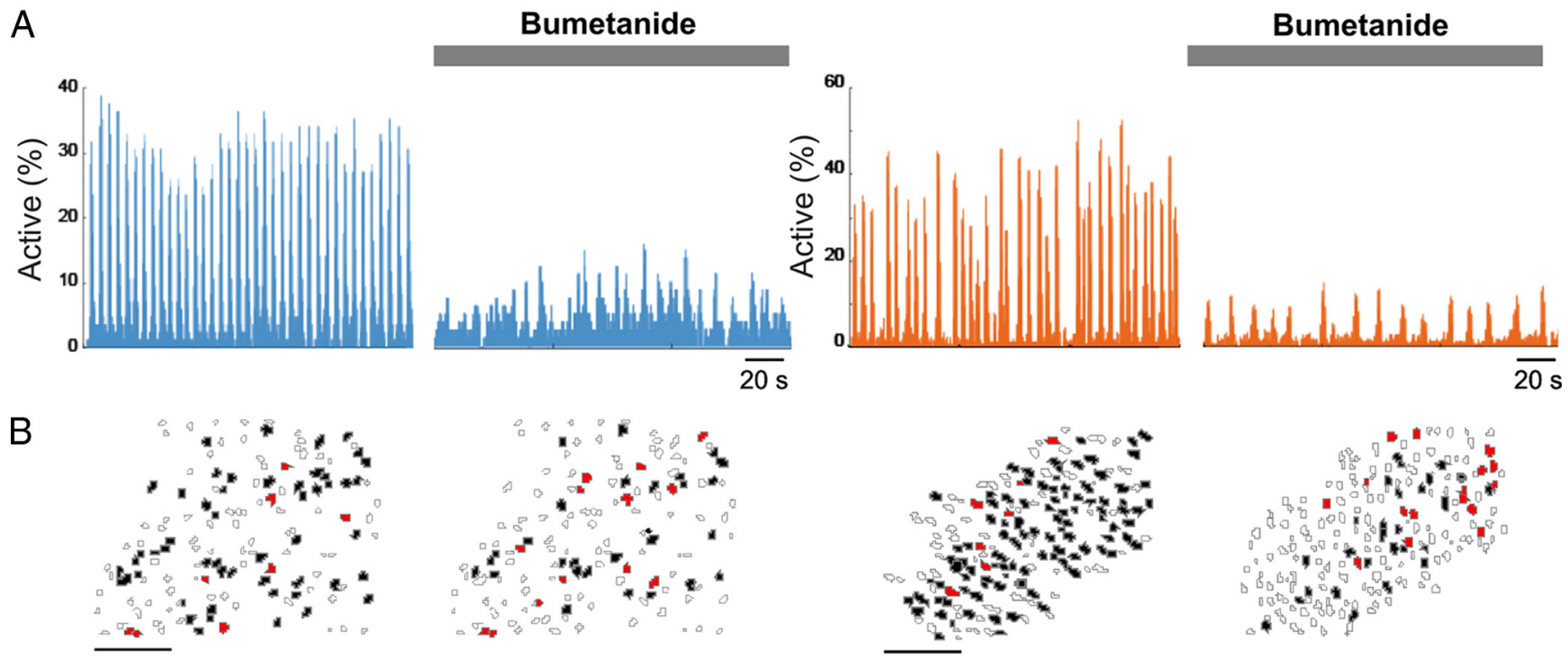

ACSF $4 \mathrm{mM} \mathrm{BHB}$

Bumetanide
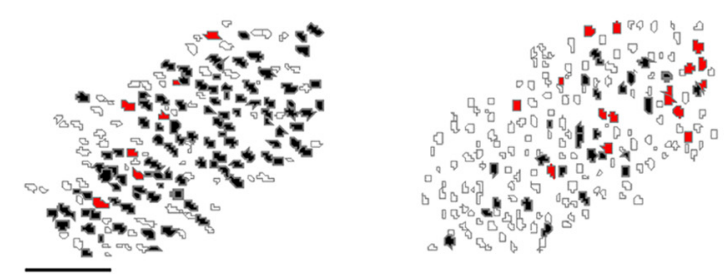

C
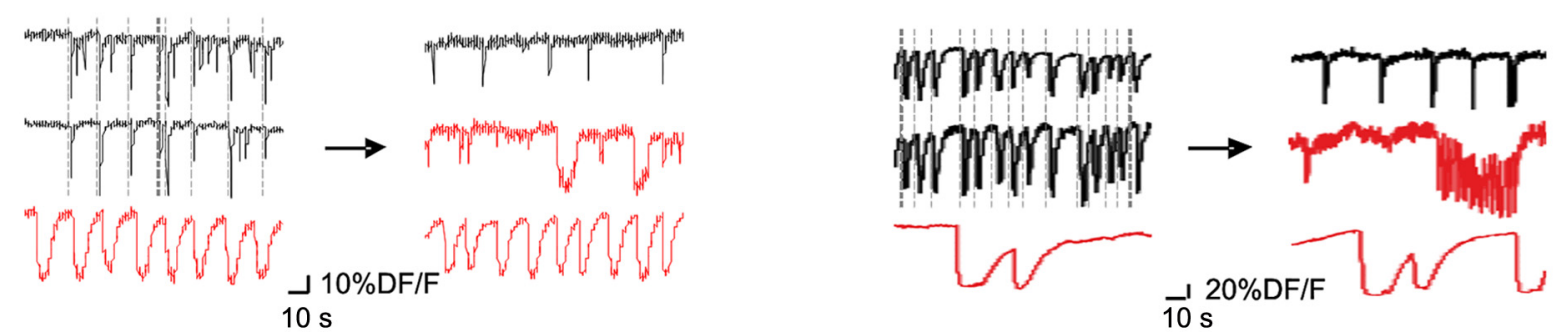

Figure 5. DL-BHB does not alter spontaneous neuronal activity patterns in neocortical slices. A, Histograms indicating the fraction of active cells as a function of time in calcium movies in regular ACSF and in the presence of $4 \mathrm{~mm} \mathrm{DL-BHB} \mathrm{(Sigma-Aldrich).} \mathrm{Each} \mathrm{peak} \mathrm{of} \mathrm{synchronous} \mathrm{neuronal} \mathrm{activity} \mathrm{in} \mathrm{the} \mathrm{histograms} \mathrm{corresponds} \mathrm{to} \mathrm{a} \mathrm{GDP.} \mathrm{GDPs} \mathrm{were} \mathrm{strongly} \mathrm{reduced} \mathrm{in} \mathrm{the} \mathrm{presence} \mathrm{of} \mathrm{the}$ NKCC1 antagonist bumetanide $(10 \mu \mathrm{m})$ in neocortical slices from P7 rats. $\boldsymbol{B}$, Automatically detected contours of the imaged cells: open contours indicate silent cells, black filled contours indicate cells involved in GDPs, and red filled contours are SPA cells. Note that the number of SPA cells relative to the number of active cells increased in the presence of $10 \mu \mathrm{m}$ bumetanide in the neocortex and hippocampus (scale bar, $100 \mu \mathrm{m}$ ). C, Calcium fluorescence traces of representative cells implicated in GDPs (black) and SPAs (red). Note that some GDP cells display an SPA pattern of activity after adding bumetanide (middle traces).

Table 3. Dynamics of cortical GDPs and SPAs in regular ACSF and in the presence of DL-BHB (Sigma-Aldrich)

\begin{tabular}{lcl}
\hline & Regular ACSF & ACSF + DL-BHB at 4 mM \\
\hline$n$ & 7 & 5 \\
$\operatorname{GDP}_{\text {freq }}(\mathrm{Hz})$ & $0.12 \pm 0.02$ & $0.14 \pm 0.05$ \\
$\mathrm{GDP}_{\text {amp }}(\%)$ & $22 \pm 3$ & $22 \pm 4$ \\
SPA cells (\%) & $8 \pm 2$ & $17 \pm 11$ \\
\hline
\end{tabular}

$\mathrm{GDP}_{\text {freq }}$, Frequency of occurrence of GDPs (in hertz); GDP ${ }_{\text {amp }}$, fraction of active cells involved in GDPs (percentage); SPA cells, fraction of active cells involved in SPAs (percentage).

\section{Discussion}

We show that neither DL-BHB, used in similar concentrations as Zilberter and colleagues, nor pyruvate at physiologically relevant concentrations alters GABA depolarizing actions and GDPs, suggesting that depolarizing GABA and GDPs in immature neurons are not attributable "to energy deprived conditions when relying only on glucose" (Rheims et al., 2009; Holmgren et al., 2010).

\section{Possible reasons for the discrepancies}

DL-BHB at $4 \mathrm{~mm}$ (Sigma-Aldrich) had no effects on (1) $E_{\mathrm{m}}$, $E_{\mathrm{GABA}}$, and $\mathrm{DF}_{\mathrm{GABA}}$ in somatic recordings of single GABA and NMDA channels, (2) $E_{\mathrm{m}}$, synaptic GABAergic potentials and the responses evoked by GABA application in gramicidin perforated patch recordings, (3) spikes generated by GABA in cell-attached recordings, and (4) frequency of GDPs or SPAs relying on calcium imaging and electrophysiological recordings.

The wide range of $E_{\mathrm{GABA}}$ values reported by Holmgren et al. (2010) suggests a heterogeneity possibly attributable to pooling different ages particularly between $\mathrm{P} 1$ and $\mathrm{P} 4$ in which major shifts occur in $E_{\mathrm{GABA}}$ (Tyzio et al., 2006, 2007) in superficial and deep neocortical layers neurons or CA1 and CA3 pyramidal neurons with their different age (Ben-Ari et al., 2007; Rheims et al., 2008). Additional explanations to the discrepancy between the present study and the work of Zilberter and colleagues include the experimental approaches to measure $E_{\mathrm{GABA}}$. (1) Cell-attached recordings of GABA channels without potassium channel blockers in the pipette could be contaminated by potassium channels and shift the measures to potassium reversal. (2) Prolonged activation of GABA receptors by long $(2 \mathrm{~s})$ isoguvacine applications and voltage ramps at the peak of the response used to determine $E_{\mathrm{GABA}}$ can be associated with profound changes in ionic distribution. Here, we used brief (50-200 ms) isoguvacine applications and synaptic stimulations at different holding potentials to minimize the error. (3) The "random" burst protocol used to record the spikes evoked by synaptic activation of GABA receptors may introduce activity-dependent disturbance in ionic gradients (the same applies for repetitive puff application of isoguvacine). This was controlled in the present study by wash in 

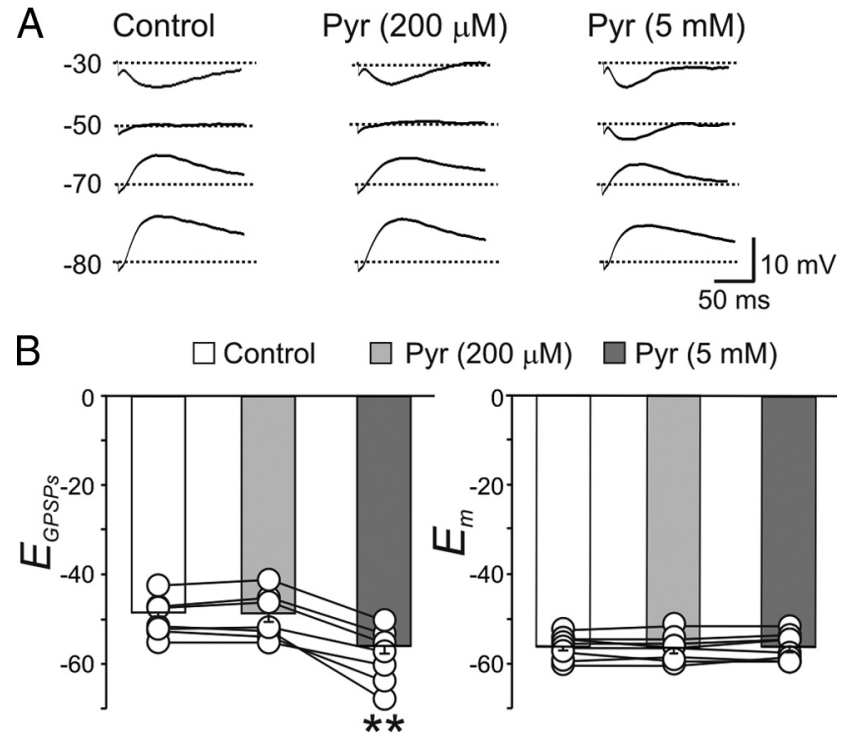

Figure 6. $E_{G \mathrm{PSP}}$ shift in the presence of high but not low concentrations of pyruvate. $\boldsymbol{A}$, Examples of $G A B A_{A}$-mediated postsynaptic potentials evoked in control (white, left), in the presence of $200 \mu \mathrm{m}$ pyruvate (Pyr) (light gray, middle), and in the presence of $5 \mathrm{~mm}$ pyruvate (dark gray, right). $\boldsymbol{B}, 0$ pen circles represent $E_{\text {GPSP }}$ (graph on the left) and $E_{\mathrm{m}}$ (graph on the right) obtained in individual cells recorded in normal ACSF (white columns; left), in ACSF containing $200 \mu \mathrm{m}$ (light gray; middle) or $5 \mathrm{~mm}$ (dark gray; right) pyruvate $(n=7)$. Bars at the top of the columns represent the SEM. Note the negative shift of $E_{\text {GPSPs }}$ but not in $E_{\mathrm{m}}$ of cells exposed to 5 mм pyruvate. The mean $E_{\text {GPSP }}$ value obtained in $5 \mathrm{~mm}$ pyruvate was significantly different from that obtained in control $(p=0.003)$ and in $200 \mu \mathrm{m}$ pyruvate $(p=0.005) .{ }^{* *} p<0.01$.
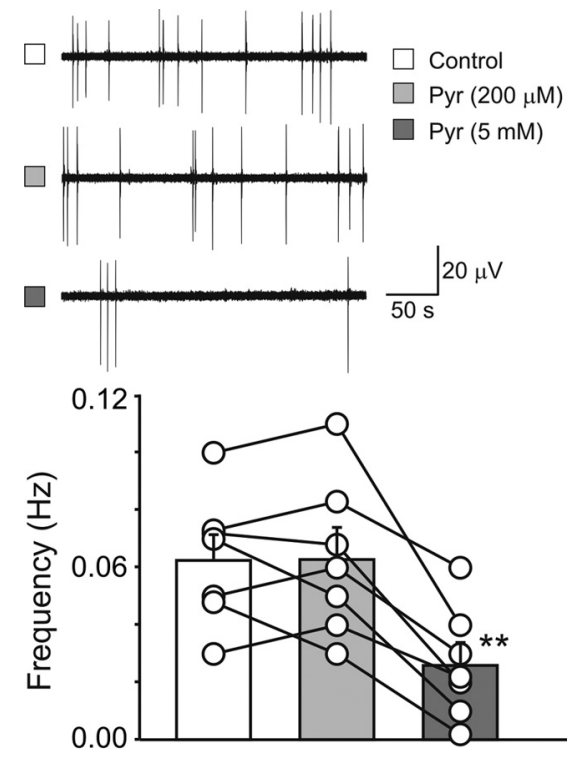

Figure 7. High but not low concentrations of pyruvate reduce GDPs frequency. On the left, sample traces of spontaneous GDPs recorded from the same slice before (white symbol; top trace) or during exposure to $200 \mu \mathrm{m}$ pyruvate (Pyr) (light gray; middle trace) and 5 mм pyruvate (dark gray; bottom trace). Note the reduction in GDPs frequency with $5 \mathrm{~mm}$ but not $200 \mu \mathrm{m}$ pyruvate. On the right, each symbol represents the mean frequency value of GDPs obtained in individual slices before (white column) or during exposure to $200 \mu \mathrm{m}$ (light gray) and $5 \mathrm{~mm}$ (dark gray; right) pyruvate $(n=7)$. Bars at the top of the columns represent the SEM. The mean GDPs frequency value obtained in $5 \mathrm{~mm}$ pyruvate was significantly different from that obtained in control $(p=0.005)$ and in $200 \mu \mathrm{m}$ pyruvate $(p=0.005) .{ }^{*} p<0.05$.

and washout of bicuculline or bumetanide. Finally, the noninvasive quantitative determination of the percentage of neurons active during SPAs and GDPs suggests that both DL-BHB and pyruvate have no effects on these patterns.
The presence of a contaminant dibenzylamine in DL-BHB (Acros Organics) that changes $\mathrm{DF}_{\mathrm{GABA}}$ and $E_{\mathrm{GABA}}$ is important for future studies. DBA mediates effects thought previously to be attributable to DL-BHB blockade of cardiac $\mathrm{K}^{+}$channels and anticonvulsive actions of ketone bodies (Doepner et al., 1997, 2001; Rho et al., 2002; Donevan et al., 2003). Investigations using DL-BHB must take this parameter into account.

\section{Physiologically relevant concentrations of $\mathrm{D}-\mathrm{BHB}$, lactate, and pyruvate}

Neonatal plasma concentrations of D-BHB (present results; see also Nehlig and Pereira de Vasconcelos, 1993; Lust et al., 2003; Vannucci and Simpson, 2003; Erecinska et al., 2004; Nehlig, 2004) are significantly lower than those used by Rheims et al. (2009) and Holmgren et al. (2010), particularly because only a fraction $(40 \%)$ of plasma $\mathrm{D}-\mathrm{BHB}$ is found in neonatal cortex (Lust et al., 2003). In addition, the argument that $4 \mathrm{mM}$ DL-BHB is equivalent to $2 \mathrm{mM}$ active D-BHB (Rheims et al., 2009) is invalidated by the observations that L-BHB exerts complex biological actions (Moore et al., 1976; Webber and Edmond, 1977; Herzberg and Gad, 1984; Eaton et al., 2003; Tsai et al., 2006; Chou et al., 2008). Also, ketogenic diet reduces glucose utilization by $10 \%$ per millimolar plasma ketone bodies (Robinson and Williamson, 1980; Harding and Charlton, 1990; LaManna et al., 2009), hampering the interpretation and relevance of observations made using ACSF with glucose and DL-BHB.

The lactate $(5 \mathrm{~mm})$ and pyruvate $(5 \mathrm{~mm})$ concentrations used by Holmgren et al. (2010) are never observed in postnatal physiological conditions. Plasma lactate levels are high in utero (10 $\mathrm{mm}$ ), shift to $3 \mathrm{~mm}$ during the presuckling period, and remain thereafter close to $1 \mathrm{~mm}$ (Medina, 1985), and even then glucose supplies most of the energy (Burd et al., 1975; Jones et al., 1975; Pégorier et al., 1977). The plasma lactate/pyruvate ratio is close to 10 (with $100 \mu \mathrm{M}$ pyruvate), and higher lactate and (or) lactate/ pyruvate ratios are only observed in dystonia, subarachnoid hemorrhage, brain traumas, epilepsies, pyruvate dehydrogenase mutations, and other severe pathological conditions (Owen et al., 1967; Medina, 1985; Fernandez et al., 1986; Mintun et al., 2004; Bjerring et al., 2008; Brody et al., 2008; Rex et al., 2009). In keeping with this, we found pyruvate levels $\sim 120 \mu \mathrm{M}$ that are identical to human levels and 40 -fold lower than the concentrations used by Zilberter and colleagues. At physiological levels, pyruvate and lactate had no effects on excitatory actions of $\mathrm{GABA}, \mathrm{DF}_{\mathrm{GABA}}$, and GDPs.

The reduction of $\mathrm{DF}_{\mathrm{GABA}}$ and GDPs by exceedingly high concentrations of pyruvate $(5 \mathrm{~mm})$ is most likely attributable to the acidosis produced at these concentrations. Agents that alter tissue pH alter intracellular chloride (Kaila and Voipio, 1987; Kaila et al., 1993; Chesler, 2003; Glykys et al., 2009; Kim and Trussell, 2009), neuronal excitability, and seizures (Roos and Boron, 1981; Aram and Lodge, 1987; Balestrino and Somjen, 1988; Jarolimek et al., 1989; Kaila, 1994; Bonnet et al., 2000; Dulla et al., 2005, 2009; Ziemann et al., 2008). Propionate, D- and L-lactate reduce GDPs, although only L-lactate is metabolically active (Roos and Boron, 1981; Dulla et al., 2005; Ruussuvori et al., 2010). Therefore, depolarizing actions of GABA are not attributable to the absence of DL-BHB or lactate/pyruvate in the ACSF.

\section{Ketone bodies and GABA signaling}

Ketosis (Nehlig and Pereira de Vasconcelos, 1993), like transporters that import D-BHB (Pellerin et al., 1998; Magistretti et al., 1999; Bergersen et al., 2002; Pierre et al., 2002; Rafiki et al., 2003; Vannucci and Simpson, 2003; Erecinska et al., 2004) or BHB 

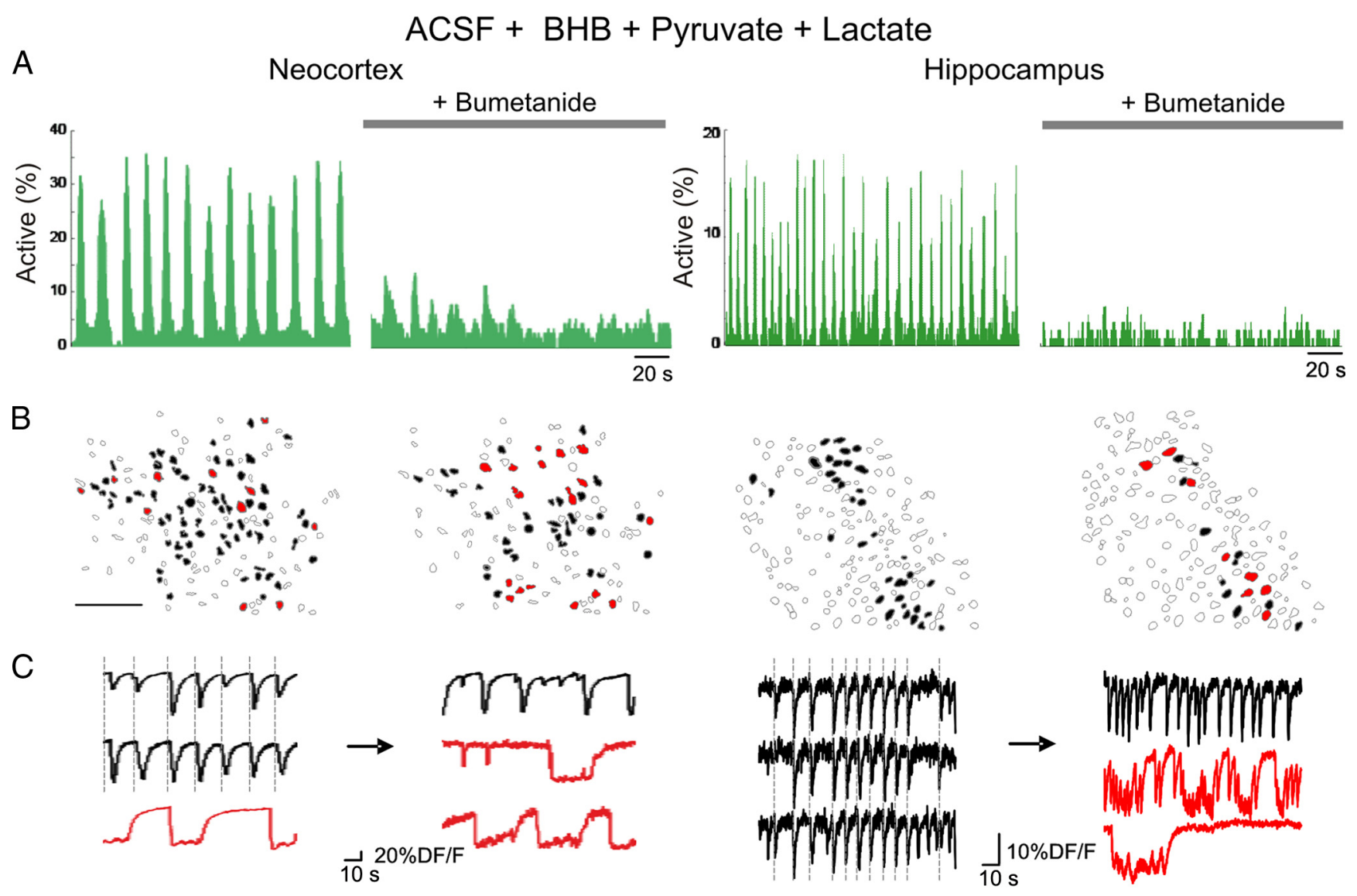

Figure 8. GDPs recorded in the presence of physiological concentrations of lactate, pyruvate, and DL-BHB are similar to those recorded in regular ACSF and are reduced by bumetanide. $A$, Histograms indicating the fraction of active cells as a function of time in calcium movies in slices incubated with $1.5 \mathrm{~mm}$ lactate, $150 \mu \mathrm{m}$ pyruvate, $5 \mathrm{~mm}$ glucose, and $4 \mathrm{~mm}$ DL-BHB (Sigma-Aldrich) for at least $1 \mathrm{~h}$. Each peak of synchronous neuronal activity in the histograms corresponds to a GDP. GDPs were strongly reduced in the presence of the NKCC 1 antagonist bumetanide (10 $\mu \mathrm{M}$ ) in neocortical and hippocampal slices from P7 rats. $\boldsymbol{B}$, Automatically detected contours of the imaged cells: open contours indicate silent cells, black filled contours indicate cells involved in GDPs, and red filled contours are SPA cells. Note that the number of SPA cells relative to the number of active cells increased in the presence of $10 \mu \mathrm{m}$ bumetanide in both the neocortex and hippocampus (scale bar, $100 \mu \mathrm{m})$. C, Calcium fluorescence traces of representative cells implicated in GDPs (black) and SPAs (red). Note that some GDP cells display an SPA pattern of activity after adding bumetanide (middle traces).

Table 4. Dynamics of cortical GDPs and SPAs in the neocortex and the hippocampus in the presence of physiological concentrations of lactate, pyruvate, and DL-BHB

\begin{tabular}{llc}
\hline ACSF and DL-BHB + Pyruvate + Lactate & Neocortex & Hippocampus \\
\hline$n$ & 5 & 3 \\
$\operatorname{GDP}_{\text {freq }}(\mathrm{Hz})$ & $0.1 \pm 0.02$ & $0.07 \pm 0.03$ \\
$\mathrm{GDP}_{\text {amp }}(\%)$ & $60 \pm 10$ & $13 \pm 1$ \\
SPA cells (\%) & $16 \pm 4$ & $3 \pm 0.003$
\end{tabular}

$\mathrm{GDP}_{\text {freq }}$, Frequency of occurrence of GDPs (in hertz); GDP amp , fraction of active cells involved in GDPs (percentage); SPA cells, fraction of active cells involved in SPAs (percentage).

dehydrogenase that metabolize it (Page et al., 1971; De Vivo et al., 1975; Leong and Clark, 1984; Bilger and Nehlig, 1991; Clark et al., 1993), peak during development well after the GABA shift. Fatty acid oxidation supports gluconeogenesis (Pégorier et al., 1977), and ketosis acts to "spare glucose for the emergence of audition, vision and more integrated behavior whose appearance during brain maturation seems to critically relate upon active glucose supply" (Nehlig, 2004). GABA currents are not affected by DL$\mathrm{BHB}$ and ketogenic diet reduces seizures generated by GABA receptor antagonists (Appleton and De Vivo, 1973, 1974; Bough and Eagles, 1999; Bough et al., 2000; Thio et al., 2000; Sullivan et al., 2003; Hartman et al., 2007; Yellen, 2008; Maalouf et al., 2009), suggesting, contrary to Zilberter and colleagues, that the antiepileptic actions of ketone bodies are not mediated by GABA signal- ing. GABA depolarizes immature neurons in nonmammalian animal species and in utero in rodents, suggesting that maternal milk and ketone bodies are not required for that effect (Akerman and Cline, 2006; Ben-Ari et al., 2007).

\section{The NKCC1/KCC2 sequence in brain maturation}

Contrary to the suggestions of Zilberter and colleagues (Rheims et al., 2009; Holmgren et al., 2010), extensive pharmacological, anatomical, and genetic observations suggest that the removal of chloride in neonatal pups heavily depends on KCC2 (Li et al., 2002; Rheims et al., 2008; Riekki et al., 2008; Zhu et al., 2008; Takayama and Inoue, 2010). The parallel alterations of KCC2 and GABA polarity have been confirmed in a large variety of animal species from invertebrates to humans (Rivera et al., 1999, 2005; Delpire, 2000; Payne et al., 2003; Sernagor et al., 2003; Dzhala et al., 2005; Akerman and Cline, 2006; Liu et al., 2006; Ben-Ari et al., 2007; Howard et al., 2007; Kahle et al., 2008; Reynolds et al., 2008; Blaesse et al., 2009; Glykys et al., 2009; Stil et al., 2009; Tanis et al., 2009; Boulenguez et al., 2010). KCC2 and $E_{\mathrm{GABA}}$ developmental sequences are unlikely to depend on global metabolic diets because they are cell and sex specific (Kandler and Friauf, 1995; Kandler et al., 2002; Balakrishnan et al., 2003; Gulacsi et al., 2003; Lee et al., 2005; Lohrke et al., 2005; Banke and McBain, 2006; Blaesse et al., 2006; Kim and Trussell, 2009; Belenky et al., 2010). Neurons in which GABA remains depolar- 
izing do not express KCC2 (Price et al., 2005; Gilbert et al., 2007; Pozas et al., 2008), and early overexpression of KCC2 in zebra fish embryos (Reynolds et al., 2008) or cortical neurons (Chudotvorova et al., 2005; Lee et al., 2005; Ben-Ari et al., 2007; Cancedda et al., 2007; Wang and Kriegstein, 2008) alter GABA polarity, GABA synapse formation, and neuronal development in vivo. KCC2 is downregulated by activity and $E_{\mathrm{GABA}}$ shifts accordingly (Woodin et al., 2003; Fiumelli et al., 2005).

Neonatal slices are not energy deprived in $10 \mathrm{~mm}$ glucose because they have a low rate of oxygen and glucose consumption and are less susceptible to energy deprivation than adult slices (Cherubini et al., 1989; Novotny et al., 2001; Tyzio et al., 2006). Lowering glucose reduces GDPs, ATP levels, and mitochondrial $\mathrm{pH}$, confirming the sensitivity of GDPs to energy deprivation, but these are not restored by lactate (Takata and Okada, 1995; Wada et al., 1998; Takata et al., 2001) (Ruussuvori et al., unpublished report). Slices and intact hippocampi sustain GDPs for hours (Ben-Ari et al., 1989; Cherubini et al., 1989; Khalilov et al., 1997, 2003; Leinekugel et al., 1997; Safiulina et al., 2006) and are replaced by glutamate-driven early network oscillations when energy is deprived (Allène et al., 2008).

We conclude that the depolarizing action of GABA and related network-driven GDPs in immature cortical slices are not attributable to metabolic insufficiency. Therefore, conventional glucose containing ACSF provides adequate energy supply for cortical slices in vitro.

\section{References}

Akerman CJ, Cline HT (2006) Depolarizing GABAergic conductances regulate the balance of excitation to inhibition in the developing retinotectal circuit in vivo. J Neurosci 26:5117-5130.

Allène C, Cattani A, Ackman JB, Bonifazi P, Aniksztejn L, Ben-Ari Y, Cossart $\mathrm{R}$ (2008) Sequential generation of two distinct synapse-driven network patterns in developing neocortex. J Neurosci 28:12851-12863.

Appleton DB, De Vivo DC (1973) An experimental animal model for the effect of ketogenic diet on epilepsy. Proc Aust Assoc Neurol 10:75-80.

Appleton DB, DeVivo DC (1974) An animal model for the ketogenic diet. Epilepsia 15:211-227.

Aram JA, Lodge D (1987) Epileptiform activity induced by alkalosis in rat neocortical slices: block by antagonists of $N$-methyl-D-aspartate. Neurosci Lett 83:345-350.

Balakrishnan V, Becker M, Löhrke S, Nothwang HG, Güresir E, Friauf E (2003) Expression and function of chloride transporters during development of inhibitory neurotransmission in the auditory brainstem. J Neurosci 23:4134-4145.

Balestrino M, Somjen GG (1988) Concentration of carbon dioxide, interstitial $\mathrm{pH}$ and synaptic transmission in hippocampal formation of the rat. J Physiol 396:247-266.

Banke TG, McBain CJ (2006) GABAergic input onto CA3 hippocampal interneurons remains shunting throughout development. J Neurosci 26:11720-11725.

Barry PH, Lynch JW (1991) Liquid junction potentials and small cell effects in patch-clamp analysis. J Membr Biol 121:101-117.

Belenky MA, Sollars PJ, Mount DB, Alper SL, Yarom Y, Pickard GE (2010) Cell-type specific distribution of chloride transporters in the rat suprachiasmatic nucleus. Neuroscience 165:1519-1537.

Ben-Ari Y (2001) Developing networks play similar melody. Trends Neurosci 24:354-360.

Ben-Ari Y (2002) Excitatory actions of gaba during development: the nature of the nurture. Nat Rev Neurosci 3:728-739.

Ben-Ari Y, Cherubini E, Corradetti R, Gaiarsa JL (1989) Giant synaptic potentials in immature rat CA3 hippocampal neurones. J Physiol 416:303-325.

Ben-Ari Y, Gaiarsa JL, Tyzio R, Khazipov R (2007) GABA: a pioneer transmitter that excites immature neurons and generates primitive oscillations. Physiol Rev 87:1215-1284.

Bergersen L, Rafiki A, Ottersen OP (2002) Immunogold cytochemistry identifies specialized membrane domains for monocarboxylate transport in the central nervous system. Neurochem Res 27:89-96.
Bilger A, Nehlig A (1991) Quantitative histochemical changes in enzymes involved in energy metabolism in the rat brain during postnatal development. I. Cytochrome oxidase and lactate dehydrogenase. Int J Dev Neurosci 9:545-553.

Bjerring PN, Hauerberg J, Frederiksen HJ, Jorgensen L, Hansen BA, Tofteng F, Larsen FS (2008) Cerebral glutamine concentration and lactatepyruvate ratio in patients with acute liver failure. Neurocrit Care 9:3-7.

Blaesse P, Guillemin I, Schindler J, Schweizer M, Delpire E, Khiroug L, Friauf E, Nothwang HG (2006) Oligomerization of KCC2 correlates with development of inhibitory neurotransmission. J Neurosci 26:10407-10419.

Blaesse P, Airaksinen MS, Rivera C, Kaila K (2009) Cation-chloride cotransporters and neuronal function. Neuron 61:820-838.

Bonifazi P, Goldin M, Picardo MA, Jorquera I, Cattani A, Bianconi G, Represa A, Ben-Ari Y, Cossart R (2009) GABAergic hub neurons orchestrate synchrony in developing hippocampal networks. Science 326:1419-1424.

Bonnet U, Leniger T, Wiemann M (2000) Alteration of intracellular pH and activity of CA3-pyramidal cells in guinea pig hippocampal slices by inhibition of transmembrane acid extrusion. Brain Res 872:116-124.

Bough KJ, Eagles DA (1999) A ketogenic diet increases the resistance to pentylenetetrazole-induced seizures in the rat. Epilepsia 40:138-143.

Bough KJ, Yao SG, Eagles DA (2000) Higher ketogenic diet ratios confer protection from seizures without neurotoxicity. Epilepsy Res 38:15-25.

Boulenguez P, Liabeuf S, Bos R, Bras H, Jean-Xavier C, Brocard C, Stil A, Darbon P, Cattaert D, Delpire E, Marsala M, Vinay L (2010) Downregulation of the potassium-chloride cotransporter KCC2 contributes to spasticity after spinal cord injury. Nat Med 16:302-307.

Brody DL, Magnoni S, Schwetye KE, Spinner ML, Esparza TJ, Stocchetti N, Zipfel GJ, Holtzman DM (2008) Amyloid-beta dynamics correlate with neurological status in the injured human brain. Science 321:1221-1224.

Burd LI, Jones MD Jr, Simmons MA, Makowski EL, Meschia G, Battaglia FC (1975) Placental production and foetal utilisation of lactate and pyruvate. Nature 254:710-711.

Cancedda L, Fiumelli H, Chen K, Poo MM (2007) Excitatory GABA action is essential for morphological maturation of cortical neurons in vivo. J Neurosci 27:5224-5235.

Cherubini E, Ben-Ari Y, Krnjević K (1989) Anoxia produces smaller changes in synaptic transmission, membrane potential, and input resistance in immature rat hippocampus. J Neurophysiol 62:882-895.

Chesler M (2003) Regulation and modulation of $\mathrm{pH}$ in the brain. Physiol Rev 83:1183-1221.

Chou YC, Tsai YC, Chen CM, Chen SM, Lee JA (2008) Determination of lipoprotein lipase activity in post heparin plasma of streptozotocininduced diabetic rats by high-performance liquid chromatography with fluorescence detection. Biomed Chromatogr 22:502-510.

Chudotvorova I, Ivanov A, Rama S, Hübner CA, Pellegrino C, Ben-Ari Y, Medina I (2005) Early expression of KCC2 in rat hippocampal cultures augments expression of functional GABA synapses. J Physiol 566:671-679.

Clark JB, Bates TE, Cullingford T, Land JM (1993) Development of enzymes of energy metabolism in the neonatal mammalian brain. Dev Neurosci 15:174-180.

Crépel V, Aronov D, Jorquera I, Represa A, Ben-Ari Y, Cossart R (2007) A parturition-associated nonsynaptic coherent activity pattern in the developing hippocampus. Neuron 54:105-120.

Delpire E (2000) Cation-chloride cotransporters in neuronal communication. News Physiol Sci 15:309-312.

DeVivo DC, Leckie MP, Agrawal HC (1975) D-beta-Hydrozybutyrate: a major precursor of amino acids in developing rat brain. J Neurochem 25:161-170.

Doepner B, Thierfelder S, Hirche H, Benndorf K (1997) 3-hydroxybutyrate blocks the transient $\mathrm{K}^{+}$outward current in myocardial mouse cells in a stereoselective fashion. J Physiol 500:85-94 [retraction in J Physiol (1998) 508:956].

Doepner B, Koopmann R, Knopp A, Hirche H, Benndorf K (2001) Dibenzylamine: a novel blocker of the voltage-dependent $\mathrm{K}^{+}$current in myocardial mouse cells. Naunyn Schmiedebergs Arch Pharmacol 364:9-13.

Donevan SD, White HS, Anderson GD, Rho JM (2003) Voltage-dependent block of $N$-methyl-D-aspartate receptors by the novel anticonvulsant dibenzylamine, a bioactive constituent of $\mathrm{L}-(+)$-beta-hydroxybutyrate. Epilepsia 44:1274-1279.

Dulla CG, Dobelis P, Pearson T, Frenguelli BG, Staley KJ, Masino SA (2005) 
Adenosine and ATP link PCO2 to cortical excitability via pH. Neuron 48:1011-1023.

Dulla CG, Frenguelli BG, Staley KJ, Masino SA (2009) Intracellular acidification causes adenosine release during states of hyperexcitability in the hippocampus. J Neurophysiol 102:1984-1993.

Dzhala V, Desfreres L, Melyan Z, Ben-Ari Y, Khazipov R (1999) Epileptogenic action of caffeine during anoxia in the neonatal rat hippocampus. Ann Neurol 46:95-102.

Dzhala VI, Talos DM, Sdrulla DA, Brumback AC, Mathews GC, Benke TA, Delpire E, Jensen FE, Staley KJ (2005) NKCC1 transporter facilitates seizures in the developing brain. Nat Med 11:1205-1213.

Eaton S, Chatziandreou I, Krywawych S, Pen S, Clayton PT, Hussain K (2003) Short-chain 3-hydroxyacyl-CoA dehydrogenase deficiency associated with hyperinsulinism: a novel glucose-fatty acid cycle? Biochem Soc Trans 31:1137-1139.

Erecinska M, Cherian S, Silver IA (2004) Energy metabolism in mammalian brain during development. Prog Neurobiol 73:397-445.

Fernandez F, Verdu A, Quero J, Ferreiros MC, Daimiel E, Roche MC, LopezMartin V (1986) Cerebrospinal fluid lactate levels in term infants with perinatal hypoxia. Pediatr Neurol 2:39-42.

Ferré P, Satabin P, Decaux JF, Escriva F, Girard J (1983) Development and regulation of ketogenesis in hepatocytes isolated from newborn rats. Biochem J 214:937-942.

Fiumelli H, Cancedda L, Poo MM (2005) Modulation of GABAergic transmission by activity via postsynaptic $\mathrm{Ca}^{2+}$-dependent regulation of KCC2 function. Neuron 48:773-786.

Ganguly K, Schinder AF, Wong ST, Poo M (2001) GABA itself promotes the developmental switch of neuronal GABAergic responses from excitation to inhibition. Cell 105:521-532.

Garaschuk O, Hanse E, Konnerth A (1998) Developmental profile and synaptic origin of early network oscillations in the CA1 region of rat neonatal hippocampus. J Physiol 507:219-236.

Gilbert D, Franjic-Würtz C, Funk K, Gensch T, Frings S, Möhrlen F (2007) Differential maturation of chloride homeostasis in primary afferent neurons of the somatosensory system. Int J Dev Neurosci 25:479-489.

Glykys J, Dzhala VI, Kuchibhotla KV, Feng G, Kuner T, Augustine G, Bacskai BJ, Staley KJ (2009) Differences in cortical versus subcortical GABAergic signaling: a candidate mechanism of electroclinical uncoupling of neonatal seizures. Neuron 63:657-672.

Gulácsi A, Lee CR, Sík A, Viitanen T, Kaila K, Tepper JM, Freund TF (2003) Cell type-specific differences in chloride-regulatory mechanisms and $\mathrm{GABA}_{\mathrm{A}}$ receptor-mediated inhibition in rat substantia nigra. J Neurosci 23:8237-8246.

Harding JE, Charlton VE (1990) Effect of lactate and beta-hydroxybutyrate infusions on brain metabolism in the fetal sheep. J Dev Physiol 14:139-146.

Hartman AL, Gasior M, Vining EP, Rogawski MA (2007) The neuropharmacology of the ketogenic diet. Pediatr Neurol 36:281-292.

Herzberg GR, Gad M (1984) Evidence that the cytosolic activity of 3-hydroxybutyrate dehydrogenase in chicken liver is L-3-hydroxyacid dehydrogenase. Biochim Biophys Acta 802:67-70.

Holmgren CD, Mukhtarov M, Malkov AE, Popova IY, Bregestovski P, Zilberter Y (2010) Energy substrate availability as a determinant of neuronal resting potential, GABA signaling and spontaneous network activity in the neonatal cortex in vitro. J Neurochem 112:900-912.

Howard MA, Burger RM, Rubel EW (2007) A developmental switch to GABAergic inhibition dependent on increases in Kv1-type $\mathrm{K}^{+}$currents. J Neurosci 27:2112-2123.

Jarolimek W, Misgeld U, Lux HD (1989) Activity dependent alkaline and acid transients in guinea pig hippocampal slices. Brain Res 505:225-232.

Jones MD Jr, Burd LI, Makowski EL, Meschia G, Battaglia FC (1975) Cerebral metabolism in sheep: a comparative study of the adult, the lamb, and the fetus. Am J Physiol 229:235-239.

Kahle KT, Staley KJ, Nahed BV, Gamba G, Hebert SC, Lifton RP, Mount DB (2008) Roles of the cation-chloride cotransporters in neurological disease. Nat Clin Pract Neurol 4:490-503.

Kaila K (1994) Ionic basis of GABAA receptor channel function in the nervous system. Prog Neurobiol 42:489-537.

Kaila K, Voipio J (1987) Postsynaptic fall in intracellular pH induced by GABA-activated bicarbonate conductance. Nature 330:163-165.

Kaila K, Voipio J, Paalasmaa P, Pasternack M, Deisz RA (1993) The role of bicarbonate in GABAA receptor-mediated IPSPs of rat neocortical neurones. J Physiol 464:273-289.

Kandler K, Friauf E (1995) Development of glycinergic and glutamatergic synaptic transmission in the auditory brainstem of perinatal rats. J Neurosci 15:6890-6904.

Kandler K, Kullmann PH, Ene FA, Kim G (2002) Excitatory action of an immature glycinergic/GABAergic sound localization pathway. Physiol Behav 77:583-587.

Khalilov I, Esclapez M, Medina I, Aggoun D, Lamsa K, Leinekugel X, Khazipov R, Ben-Ari Y (1997) A novel in vitro preparation: the intact hippocampal formation. Neuron 19:743-749.

Khalilov I, Holmes GL, Ben-Ari Y (2003) In vitro formation of a secondary epileptogenic mirror focus by interhippocampal propagation of seizures. Nat Neurosci 6:1079-1085.

Kim Y, Trussell LO (2009) Negative shift in the glycine reversal potential mediated by a $\mathrm{Ca}^{2+}$ - and $\mathrm{pH}$-dependent mechanism in interneurons. J Neurosci 29:11495-11510.

LaManna JC, Salem N, Puchowicz M, Erokwu B, Koppaka S, Flask C, Lee Z (2009) Ketones suppress brain glucose consumption. Adv Exp Med Biol 645:301-306.

Lee H, Chen CX, Liu YJ, Aizenman E, Kandler K (2005) KCC2 expression in immature rat cortical neurons is sufficient to switch the polarity of GABA responses. Eur J Neurosci 21:2593-2599.

Leinekugel X, Medina I, Khalilov I, Ben-Ari Y, Khazipov R (1997) $\mathrm{Ca}^{2+}$ oscillations mediated by the synergistic excitatory actions of $\mathrm{GABA}_{\mathrm{A}}$ and NMDA receptors in the neonatal hippocampus. Neuron 18:243-255.

Leong SF, Clark JB (1984) Regional enzyme development in rat brain. Enzymes of energy metabolism. Biochem J 218:139-145.

Li H, Tornberg J, Kaila K, Airaksinen MS, Rivera C (2002) Patterns of cation-chloride cotransporter expression during embryonic rodent CNS development. Eur J Neurosci 16:2358-2370.

Liu Z, Neff RA, Berg DK (2006) Sequential interplay of nicotinic and GABAergic signaling guides neuronal development. Science 314:1610-1613.

Löhrke S, Srinivasan G, Oberhofer M, Doncheva E, Friauf E (2005) Shift from depolarizing to hyperpolarizing glycine action occurs at different perinatal ages in superior olivary complex nuclei. Eur J Neurosci 22:2708-2722.

Lust WD, Pundik S, Zechel J, Zhou Y, Buczek M, Selman WR (2003) Changing metabolic and energy profiles in fetal, neonatal, and adult rat brain. Metab Brain Dis 18:195-206.

Maalouf M, Rho JM, Mattson MP (2009) The neuroprotective properties of calorie restriction, the ketogenic diet, and ketone bodies. Brain Res Rev 59:293-315.

Magistretti PJ, Pellerin L, Rothman DL, Shulman RG (1999) Energy on demand. Science 283:496-497.

Medina JM (1985) The role of lactate as an energy substrate for the brain during the early neonatal period. Biol Neonate 48:237-244.

Mintun MA, Vlassenko AG, Rundle MM, Raichle ME (2004) Increased lactate/pyruvate ratio augments blood flow in physiologically activated human brain. Proc Natl Acad Sci U S A 101:659-664.

Moore TJ, Lione AP, Sugden MC, Regen DM (1976) Beta-hydroxybutyrate transport in rat brain: developmental and dietary modulations. Am J Physiol 230:619-630.

Nehlig A (2004) Brain uptake and metabolism of ketone bodies in animal models. Prostaglandins Leukot Essent Fatty Acids 70:265-275.

Nehlig A, Pereira de Vasconcelos A (1993) Glucose and ketone body utilization by the brain of neonatal rats. Prog Neurobiol 40:163-221.

Novotny EJ Jr, Ariyan C, Mason GF, O’Reilly J, Haddad GG, Behar KL (2001) Differential increase in cerebral cortical glucose oxidative metabolism during rat postnatal development is greater in vivo than in vitro. Brain Res 888:193-202.

Owen OE, Morgan AP, Kemp HG, Sullivan JM, Herrera MG, Cahill GF Jr (1967) Brain metabolism during fasting. J Clin Invest 46:1589-1595.

Owens DF, Kriegstein AR (2002) Is there more to gaba than synaptic inhibition? Nat Rev Neurosci 3:715-727.

Owens DF, Boyce LH, Davis MB, Kriegstein AR (1996) Excitatory GABA responses in embryonic and neonatal cortical slices demonstrated by gramicidin perforated-patch recordings and calcium imaging. J Neurosci 16:6414-6423.

Page MA, Krebs HA, Williamson DH (1971) Activities of enzymes of 
ketone-body utilization in brain and other tissues of suckling rats. Biochem J 121:49-53.

Payne JA, Rivera C, Voipio J, Kaila K (2003) Cation-chloride cotransporters in neuronal communication, development and trauma. Trends Neurosci 26:199-206.

Pégorier JP, Ferré P, Girard J (1977) The effects of inhibition of fatty acid oxidation in suckling newborn rats. Biochem J 166:631-634.

Pellerin L, Pellegri G, Martin JL, Magistretti PJ (1998) Expression of monocarboxylate transporter mRNAs in mouse brain: support for a distinct role of lactate as an energy substrate for the neonatal vs. adult brain. Proc Natl Acad Sci U S A 95:3990-3995.

Pierre K, Magistretti PJ, Pellerin L (2002) MCT2 is a major neuronal monocarboxylate transporter in the adult mouse brain. J Cereb Blood Flow Metab 22:586-595.

Pozas E, Paco S, Soriano E, Aguado F (2008) Cajal-Retzius cells fail to trigger the developmental expression of the $\mathrm{Cl}^{-}$extruding co-transporter KCC2. Brain Res 1239:85-91.

Price TJ, Cervero F, de Koninck Y (2005) Role of cation-chloridecotransporters (CCC) in pain and hyperalgesia. Curr Top Med Chem 5:547-555.

Rafiki A, Boulland JL, Halestrap AP, Ottersen OP, Bergersen L (2003) Highly differential expression of the monocarboxylate transporters MCT2 and MCT4 in the developing rat brain. Neuroscience 122: 677-688.

Rex A, Bert B, Fink H, Voigt JP (2009) Stimulus-dependent changes of extracellular glucose in the rat hippocampus determined by in vivo microdialysis. Physiol Behav 98:467-473.

Reynolds A, Brustein E, Liao M, Mercado A, Babilonia E, Mount DB, Drapeau P (2008) Neurogenic role of the depolarizing chloride gradient revealed by global overexpression of KCC2 from the onset of development. J Neurosci 28:1588-1597.

Rheims S, Minlebaev M, Ivanov A, Represa A, Khazipov R, Holmes GL, Ben-Ari Y, Zilberter Y (2008) Excitatory GABA in rodent developing neocortex in vitro. J Neurophysiol 100:609-619.

Rheims S, Holmgren CD, Chazal G, Mulder J, Harkany T, Zilberter T, Zilberter Y (2009) GABA action in immature neocortical neurons directly depends on the availability of ketone bodies. J Neurochem 110: $1330-1338$.

Rho JM, Anderson GD, Donevan SD, White HS (2002) Acetoacetate, acetone, and dibenzylamine (a contaminant in l-(+)-beta-hydroxybutyrate) exhibit direct anticonvulsant actions in vivo. Epilepsia 43:358-361.

Riekki R, Pavlov I, Tornberg J, Lauri SE, Airaksinen MS, Taira T (2008) Altered synaptic dynamics and hippocampal excitability but normal long-term plasticity in mice lacking hyperpolarizing $\mathrm{GABA}_{\mathrm{A}}$ receptormediated inhibition in CA1 pyramidal neurons. J Neurophysiol 99: 3075-3089.

Rivera C, Voipio J, Payne JA, Ruusuvuori E, Lahtinen H, Lamsa K, Pirvola U, Saarma M, Kaila K (1999) The $\mathrm{K}^{+} / \mathrm{Cl}^{-}$co-transporter KCC2 renders GABA hyperpolarizing during neuronal maturation. Nature 397:251-255.

Rivera C, Voipio J, Kaila K (2005) Two developmental switches in GABAergic signalling: the $\mathrm{K}^{+}-\mathrm{Cl}^{-}$cotransporter $\mathrm{KCC} 2$ and carbonic anhydrase CAVII. J Physiol 562:27-36.

Robinson AM, Williamson DH (1980) Physiological roles of ketone bodies as substrates and signals in mammalian tissues. Physiol Rev 60:143-187.

Roos A, Boron WF (1981) Regulation of intracellular pH in barnacle muscle. Kroc Found Ser 15:205-219.

Ruusuvuori E, Kirilkin I, Pandya N, Kaila K (2010) Spontaneous network events driven by depolarizing GABA action in neonatal hippocampal slices are not attributable to deficient mitochondrial energy metabolism. J Neurosci 30:15638-15642.

Safiulina VF, Fattorini G, Conti F, Cherubini E (2006) GABAergic signaling at mossy fiber synapses in neonatal rat hippocampus. J Neurosci 26:597-608.

Sernagor E, Young C, Eglen SJ (2003) Developmental modulation of retinal wave dynamics: shedding light on the GABA saga. J Neurosci 23:7621-7629.

Sipilä ST, Huttu K, Voipio J, Kaila K (2006) Intrinsic bursting of immature CA3 pyramidal neurons and consequent giant depolarizing potentials are driven by a persistent $\mathrm{Na}$ current and terminated by a slow Ca-activated $\mathrm{K}$ current. Eur J Neurosci 23:2330-2338.

Sivakumaran S, Mohajerani MH, Cherubini E (2009) At immature mossyfiber-CA3 synapses, correlated presynaptic and postsynaptic activity persistently enhances GABA release and network excitability via BDNF and cAMP-dependent PKA. J Neurosci 29:2637-2647.
Stil A, Liabeuf S, Jean-Xavier C, Brocard C, Viemari JC, Vinay L (2009) Developmental up-regulation of the potassium-chloride cotransporter type 2 in the rat lumbar spinal cord. Neuroscience 164:809-821.

Sullivan PG, Dubé C, Dorenbos K, Steward O, Baram TZ (2003) Mitochondrial uncoupling protein-2 protects the immature brain from excitotoxic neuronal death. Ann Neurol 53:711-717.

Takata T, Okada Y (1995) Effects of deprivation of oxygen or glucose on the neural activity in the guinea pig hippocampal slice: intracellular recording study of pyramidal neurons. Brain Res 683:109-116.

Takata T, Sakurai T, Yang B, Yokono K, Okada Y (2001) Effect of lactate on the synaptic potential, energy metabolism, calcium homeostasis and extracellular glutamate concentration in the dentate gyrus of the hippocampus from guinea-pig. Neuroscience 104:371-378.

Takayama C, Inoue Y (2010) Developmental localization of potassium chloride co-transporter 2 (KCC2), GABA and vesicular GABA transporter (VGAT) in the postnatal mouse somatosensory cortex. Neurosci Res 67:137-148.

Tanis JE, Bellemer A, Moresco JJ, Forbush B, Koelle MR (2009) The potassium chloride cotransporter KCC-2 coordinates development of inhibitory neurotransmission and synapse structure in Caenorhabditis elegans. J Neurosci 29:9943-9954.

Thio LL, Wong M, Yamada KA (2000) Ketone bodies do not directly alter excitatory or inhibitory hippocampal synaptic transmission. Neurology 54:325-331.

Tsai YC, Chou YC, Wu AB, Hu CM, Chen CY, Chen FA, Lee JA (2006) Stereoselective effects of 3-hydroxybutyrate on glucose utilization of rat cardiomyocytes. Life Sci 78:1385-1391.

Tyzio R, Represa A, Jorquera I, Ben-Ari Y, Gozlan H, Aniksztejn L (1999) The establishment of GABAergic and glutamatergic synapses on CA1 pyramidal neurons is sequential and correlates with the development of the apical dendrite. J Neurosci 19:10372-10382.

Tyzio R, Ivanov A, Bernard C, Holmes GL, Ben-Ari Y, Khazipov R (2003) Membrane potential of CA3 hippocampal pyramidal cells during postnatal development. J Neurophysiol 90:2964-2972.

Tyzio R, Cossart R, Khalilov I, Minlebaev M, Hübner CA, Represa A, Ben-Ari Y, Khazipov R (2006) Maternal oxytocin triggers a transient inhibitory switch in GABA signaling in the fetal brain during delivery. Science 314:1788-1792.

Tyzio R, Holmes GL, Ben-Ari Y, Khazipov R (2007) Timing of the developmental switch in $\mathrm{GABA}_{\mathrm{A}}$ mediated signalling from excitation to inhibition in CA3 rat hippocampus using gramicidin perforated patch and extracellular recordings. Epilepsia 48:96-105.

Tyzio R, Minlebaev M, Rheims S, Ivanov A, Jorquera I, Holmes GL, Zilberter Y, Ben-Ari Y, Khazipov R (2008) Postnatal changes in somatic gammaaminobutyric acid signalling in the rat hippocampus. Eur J Neurosci 27:2515-2528.

Vannucci SJ, Simpson IA (2003) Developmental switch in brain nutrient transporter expression in the rat. Am J Physiol Endocrinol Metab 285: E1127-E1134.

Vassault A, Bonnefont JP, Specola N, Saudubray JM (1991) Lactate, pyruvate and ketone bodies. In: Techniques in diagnostic human biochemical genetics a laboratory manual (Home FA, ed), pp 285-308. New York: Willey-Liss.

Wada H, Okada Y, Uzuo T, Nakamura H (1998) The effects of glucose, mannose, fructose and lactate on the preservation of neural activity in the hippocampal slices from the guinea pig. Brain Res 788:144-150.

Wang DD, Kriegstein AR (2008) GABA regulates excitatory synapse formation in the neocortex via NMDA receptor activation. J Neurosci 28:5547-5558.

Webber RJ, Edmond J (1977) Utilization of L(+)-3-hydroxybutyrate, $\mathrm{D}(-)$-3-hydroxybutyrate, acetoacetate, and glucose for respiration and lipid synthesis in the 18-day-old rat. J Biol Chem 252:5222-5226.

Woodin MA, Ganguly K, Poo MM (2003) Coincident pre-and postsynaptic activity modifies GABAergic synapses by postsynaptic changes in $\mathrm{Cl}^{-}$ transporter activity. Neuron 39:807-820.

Yellen G (2008) Ketone bodies, glycolysis, and KATP channels in the mechanism of the ketogenic diet. Epilepsia 49 [Suppl 8]:80-82.

Zhu L, Polley N, Mathews GC, Delpire E (2008) NKCC1 and KCC2 prevent hyperexcitability in the mouse hippocampus. Epilepsy Res 79:201-212.

Ziemann AE, Schnizler MK, Albert GW, Severson MA, Howard MA 3rd, Welsh MJ, Wemmie JA (2008) Seizure termination by acidosis depends on ASICla. Nat Neurosci 11:816-822. 